(2) norden 



\section{Frivilligt skydd av skog i Norden}

Bo Storrank 


\section{Frivilligt skydd av skog i Norden}

TemaNord 2008:593

(c) Nordiska ministerrådet, Köpenhamn 2008

ISBN 978-92-893-1775-7

Tryck: Ekspressen Tryk \& Kopicenter

Tryckt på miljövänligt papper som uppfyller kraven i den nordiska miljösvanemärkningen. Publikationen kan beställas på www.norden.org/order. Fler publikationer på www.norden.org/publikationer

Printed in Denmark

Nordiska ministerrådet

Store Strandstræde 18

DK-1255 Köpenhamn K

Telefon (+45) 33960200

Fax (+45) 33960202

\section{Nordiska rådet}

Store Strandstræde 18

DK-1255 Köpenhamn K

Telefon (+45) 33960400

Fax (+45) 33111870

www.norden.org

\section{Det nordiska samarbetet}

Det nordiska samarbetet är ett av världens mest omfattande regionala samarbeten. Det omfattar Danmark, Finland, Island, Norge och Sverige samt de självstyrande områdena Färöarna, Grönland och Åland.

Det nordiska samarbetet är politiskt, ekonomiskt och kulturellt förankrat och är en viktig partner i europeiskt och internationellt samarbete. Den nordiska gemenskapen arbetar för ett starkt Norden i ett starkt Europa.

Det nordiska samarbetet vill styrka nordiska och regionala intressen och värderingar i en global omvärld. Gemensamma värderingar länderna emellan bidrar till att stärka Nordens ställning som en av världens mest innovativa och konkurrenskraftiga regioner. 


\section{Innehåll}

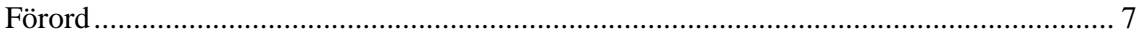

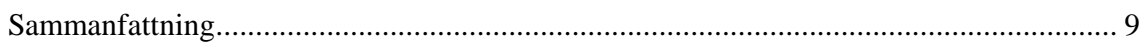

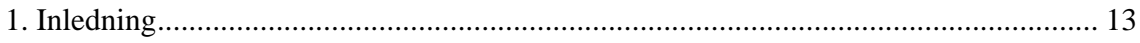

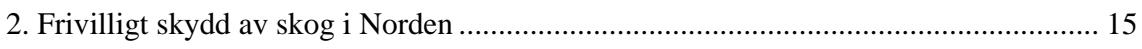

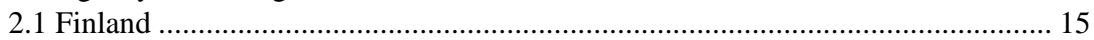

2.1.1. Bevarande av skogarnas biologiska mångfald genom METSO programmet (2003-2007) ............................................................... 16

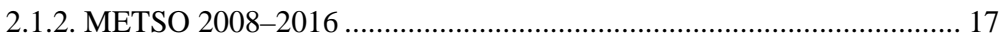

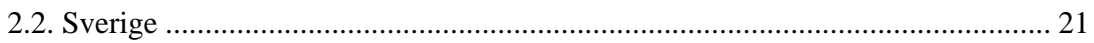

2.2.1. Miljökvalitetsmålet Levande skogar och kvantitativa mål för

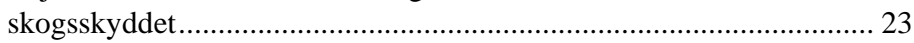

2.2.2 Kompletterande metoder vid skydd av värdefull natur......................... 24

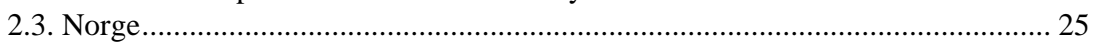

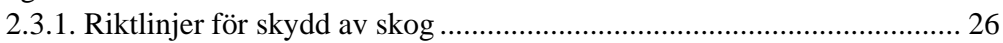

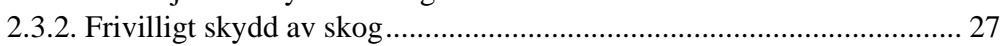

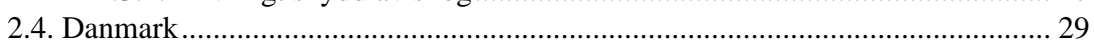

2.4.1. Frivilliga avtal enligt naturvårdslagen och skogslagen......................... 30

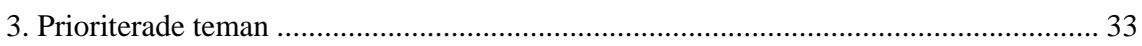

1. Kommunikation och processer som stöder lokal medverkan ................................. 33

2. Evaluering av frivilligt skydd.............................................................................. 33

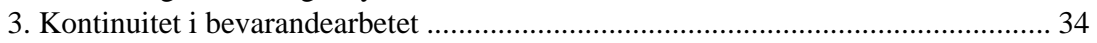

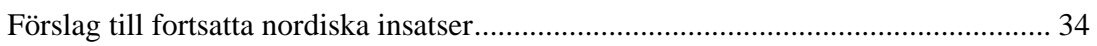

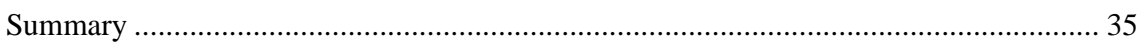

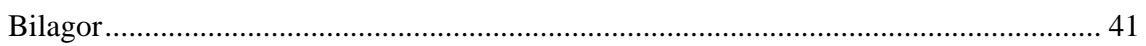

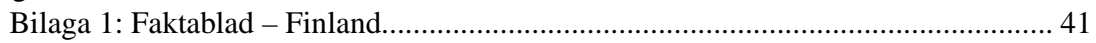

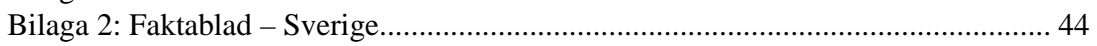

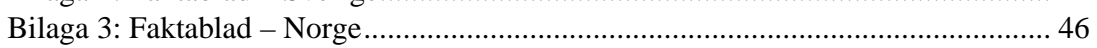

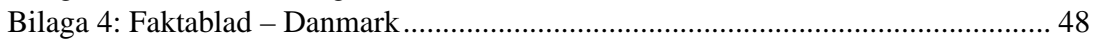

Bilaga 5: Program för seminariet i Eura, 16-18 juni 2008 ........................................ 51

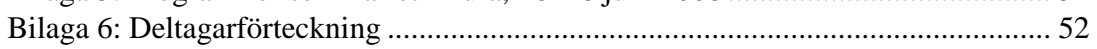





\section{Förord}

Skyddet av skog har i de nordiska länderna huvudsakligen genomförts med stöd av natur- och miljövårdslagstiftningen, men även skogslagstiftningen förutsätter hänsynstagande till miljövärden i skog inklusive avgränsning och bevarande av värdefulla biotoper. Förverkligandet av skogsskyddet har i en del fall förorsakat konflikter mellan myndigheter och skogsägare. Frivilligt skydd, som definieras något olika i de nordiska länderna, har därför under senare år framförts som ett alternativ eller komplement till mer traditionella skyddsmetoder.

Nordiska ministerrådets arbetsgrupp för natur, friluftsliv och kulturmiljö (NFK) finansierade 2008 i samarbete med styrgruppen för det nordiska miljö och jord/skogsbrukssamarbetet (MJS) projektet Frivilligt skydd av skog i Norden. Projektets huvudsakliga syfte var att intensifiera det nordiska erfarenhetsutbytet om frivilligt skydd av skog. Tidsmässigt sammanföll projektet med en period då konceptet diskuterades och politiska beslut fattades om fortsatta satsningar inom detta område, speciellt i Finland och Sverige. Tematiskt anknyter projektet till ett antal tidigare projekt finansierade av Nordiska ministerrådet och med inriktning på skogsbruk och naturvård.

Frivilligt skydd bygger i hög grad på att skogsägaren har ett starkt eget intresse av att skydda områden med höga naturvärden. Med begreppet frivilligt skydd avses i projektet därtill ett skogsskydd som bygger på ökad dialog och delaktighet i kontakterna mellan myndigheter, skogsbrukets intresseorganisationer och enskilda skogsägare. Skyddet innebär i vanliga fall att skogsägaren erhåller ekonomisk kompensation. De frivilliga avsättningarna i Sverige utgör ett undantag från denna regel. Som en del av konceptet frivilligt skydd har nya metoder för förverkligande av skyddet utvecklats. Till de mest intressanta innovationerna hör olika typer av anbudsförfaranden och samarbetsnätverk.

Det nordiska projektet utarbetade en översikt av pågående nationella processer relaterat till frivilligt skydd av skog i Finland, Sverige, Norge och Danmark (föreliggande rapport). Ett annat syfte var att utarbeta underlag för en projektansökan till EU. Som en del av detta arbete producerades en översikt av möjliga finansieringskällor inom EU. Projektet befrämjade även aktivt utarbetandet av en ansökan till miljöfonden LIFE+ .

Projektet ordnade i juni 2008 ett nordiskt seminarium i Eura, Finland. Seminariet bidrog på ett avgörande sätt till det nordiska utbytet av erfarenheter om frivilligt skydd. På seminariet presenterades statusöversikter från de deltagande länderna och praktiska erfarenheter av frivilligt skydd av skog i Finland. Diskussionerna under seminariet bidrog till att identifi- 
era några viktiga utmaningar i det fortsatta arbetet med frivilligt skydd (se bilagor).

En projektgrupp med representanter för nationella skogs- och miljömyndigheter samt skogsägarorganisationer ansvarade för projektets framdrift. Projektgruppen bidrog även med underlag till statusöversikten. I projektgruppen ingick; Tapio Lindholm, Finlands miljöcentral (ordförande), Klaus Yrjönen, Skogsbrukets utvecklingscentral Tapio, Finland, Thomas Pettersson, Naturvårdsverket, Sverige, Mikael Norén, Skogsstyrelsen, Sverige, Tove Enggrob Boon, Köpenhamns universitet, Skov og landskab, Danmark, Asbjørn Tingstad, Direktoratet for naturforvaltning, Norge och Svein M. Søgnen, Norges Skogeierforbund. Som projektkoordinator fungerade Bo Storrank, Finlands miljöcentral. I projektarbetet deltog därtill Nils Bøhn, Norges Skogeierforbund, Johan Åberg och Tove Thomasson, Skogsstyrelsen samt Kimmo Syrjänen, Finlands miljöcentral och Jarmo Uimonen, Sydvästra Finlands skogscentral. 


\section{Sammanfattning}

Nordiska ministerrådet finansierade 2008 projektet Frivilligt skydd av skog i Norden. Projektets huvudsakliga syfte var att intensifiera det nordiska erfarenhetsutbytet om frivilligt skydd av skog. Frivilligt skydd som det analyserats i detta projekt innebär att skogsägaren har ett starkt eget intresse av att skydda områden med höga naturvärden. Detta begrepp bygger därtill på ökad dialog och delaktighet i kontakterna mellan myndigheter, skogsbrukets intresseorganisationer och enskilda skogsägare.

Rapporten "Frivilligt skydd av skog i Norden” redogör för de initiativ som nyligen tagits i de nordiska länderna vad gäller denna nya form för skydd av skog. I rapporten ingår därtill en översikt av riktlinjer och övriga centrala förutsättningar för befrämjandet av det frivilliga skyddet. Projektet ordnade i juni 2008 ett seminarium i Eura, Finland, med deltagare från nordiska skogs- och miljömyndigheter, skogsägar-organisationer och forskare. Mot bakgrund av diskussionerna vid seminariet avslutas rapporten med några förslag på teman som det fortsatta arbetet kunde fokusera på, både nationellt och i ett nordiskt perspektiv.

\section{Långsiktigt skydd av skog}

Det långsiktiga, permanenta skyddet av skog i de nordiska länderna genomförs som en del av arbetet med att bevara den biologiska mångfalden. Skyddet av olika naturtyper har bl.a. förverkligats på basis av nationella skyddsprogram. Dessutom har mer specifika nationella skyddsprogram för olika typer av skog upprättats, eller program där skog ingår som en viktig naturtyp. Finland, Sverige och Danmark har som medlemmar i den Europeiska Unionen inkluderat betydande arealer skog i Natura 2000 nätverket av skyddade områden. Skog ingår i många olika typer av skyddsområden, t.ex. i naturreservat och naturskyddsområden.

\section{Skydd av värdefulla biotoper och livsmiljöer}

Skogs- respektive miljölagstiftningen i Finland, Sverige och Danmark innehåller stadganden om biotopskydd som garanterar vissa skogsbiotoper ett bestående skydd. I Finland har ett flertal viktiga typer av livsmiljöer identiferats i skogslagen, och dessa har ett automatiskt skydd som bör beaktas vid skogsbruksåtgärder. Därtill inkluderar naturvårdslagen tre naturtyper som omfattas av motsvarande föreskrifter. Miljöbalken i Sverige möjliggör inrättandet av biotopskyddsområden för att bevara mindre 
områden i skogs- och jordbrukslandskapet. Både i Finland och Sverige har landsomfattande inventeringar av viktiga livsmiljöer och biotoper genomförts. Inventeringarna har producerat ett viktigt underlag för urval av bl.a. biotopskyddsområden och hänsyn till värdefulla livsmiljöer. Även i Danmark finns stadganden om biotopskydd, som omfattar ett flertal biotoper med sin huvudsakliga förekomst i skogen. Norge har inget formellt biotopskydd direkt jämförbart med de övriga länderna, men skogs- och miljöförvaltningen har samlat in en omfattande kunskap om värdefulla biotoper i skogslandskapet.

\section{Nationella riktlinjer för skydd av skog}

Strategier och riktlinjer för fortsatt skydd av skog har formulerats både på nationell och regional nivå. Enligt det senaste svenska riksdagsbeslutet om miljökvalitetsmålen skall ytterligare 900000 ha skyddsvärd skogsmark nedanför den fjällnära regionen undantas från skogsproduktion till år 2010 (jämfört med läget 1998). Av denna areal ska 400000 hektar skyddas formellt medan skogsägarna själva förväntas avsätta 500000 hektar utan ekonomisk ersättning. Enligt den senaste utvärderingen av miljökvalitetsmålen är det osäkert om målet för skogsskydd kommer att nås till 2010.

I mars 2008 fattade regeringen (statsrådet) i Finland ett principbeslut om en handlingsplan för den biologiska mångfalden i södra Finlands skogar för perioden 2008-2016. Handlingsplanen - METSO - bygger på erfarenheterna från en omfattande försöksverksamhet under 2003-2007. Frivillighet och ökad medverkan från skogsägarna är ledande principer i förverkligandet av programmet. Enligt regeringsbeslutet våren 2008 kommer ytterligare ca 100000 ha skog i södra Finland att skyddas permanent till 2016, och därtill kommer åtgärder för befrämjande av den biologiska mångfalden att genomföras på betydande arealer i form av mer tidsbegränsade insatser.

I Norge har en utvärdering av skogsskyddet visat att det finns ett behov av att skydda minst 4,6 procent av landets produktiva skogsareal. Ett genomförande av skogsskyddet med gällande ambitionsnivå skulle förutsätta en märkbar höjning av budgetanslagen.

\section{Frivilligt skydd av skog}

Sedan början av 2000-talet har i Finland och Norge en försöksverksamhet pågått som syftat till att utreda om frivilligt skydd kunde utgöra en viktig arbetsform vid förverkligandet av skogsskyddet. Principen om frivillighet bygger på att skogsägarna själva föreslår vilka områden som kunde skyddas genom beslut av miljö- eller skogsmyndigheterna. Särskilt i Finland 
har försöksverksamheten omfattat ett flertal olika innovativa sätt att skydda skog på frivillig väg.

Förverkligandet av frivilligt skydd i Finland och Norge bygger på att miljömyndigheterna på förhand anger vilka typer av områden man önskar skydda. Kriterier för skyddsvärda områden har utarbetats på basis av naturvårdsbiologiska utgångspunkter, och de anpassas till regionala förhållanden. Ett liknande tänkesätt ligger till grund för urvalet av områden för genomförandet av det formella skyddet i Sverige, där arbetet inriktas på geografiska områden eller trakter med ett stort inslag av s.k. värdekärnor av prioriterade typer. Dessa urvalsprinciper är även möjliga att tilllämpa vid markägarnas val av frivilliga avsättningar/skydd i Sverige.

Skogsägarnas anbud, dvs deras erbjudande att skydda potentiellt viktiga områden, behandlas av de ansvariga myndigheterna i stort enligt samma rutiner som vid övriga skyddsprocesser. Detta innebär att en kvalitetsgranskning av områdenas naturvärden ingår som en del av processen. Som regel betalas alltid kompensation till markägaren för det ekonomiska bortfall skyddet medför. Initiativet till frivilligt skydd av skog kan komma dels från skogsägaren själv, dels kan behovet uppmärksammas genom kontakter t.ex. från den lokala skogsvårdsorganisationen. Pilotverksamheten i både Finland och Norge har visat att god lokalkännedom och en fungerande rådgivningsverksamhet ofta är av avgörande vikt vad gäller möjligheterna att identifiera potentiellt värdefulla skogsområden.

I Norge har det frivilliga skyddet genomförts enligt redan inarbetade rutiner för skydd av skog, och man har lyckats fånga upp ett betydande intresse för frivilligt skydd. Fram till 2008 har ca 25000 ha produktiv skog erbjudits för skydd i Norge. Permanent skydd är den skyddsform som tillämpas i Norge, dvs målet är att på basis av skogsägarens anbud inrätta bestående naturskyddsområden.

Även i Finland är ett bestående skydd den form av skydd som eftersträvas för många av de naturtyper man önskar bevara. Ett bestående skydd är med tanke på naturvärdena att föredra bl.a. i områden med ett stort inlag av död och murken ved. Vissa naturtyper kan däremot vara mer lämpade för ett tidsbundet skydd. Under pilotfasen i Finland 20032007 var det möjligt att ingå tidsbundna avtal, antingen på 10 år eller 20 år, och denna skyddsform prioriterades ofta av markägarna. Till sin karaktär motsvarar det tidsbundna skyddet i Finland en av de traditionella skyddsformerna i Sverige, dvs möjligheten att frivilligt ingå ett naturvårdsavtal. I Sverige är avtalstiden vanligen mycket längre, dvs 50 år. I båda fallen tillämpas det tidsbundna skyddet primärt i områden där olika typer av skötsel behövs för att garantera att naturvärdena bibehålls. I praktiken har tidsbundna avtal, speciellt i Finland, även upprättats för områden med naturvärden av mer permanent karaktär. 


\section{Fortsatta satsningar på frivilligt skydd}

Erfarenheterna av frivilligt skydd har i Finland och Norge till övervägande del varit positiva. I Finland utgör principen om frivillighet en bärande pelare i METSO-programmet 2008-2016, och fr o m 2010 kommer betydande ekonomiska resurser att användas för ett fortsatt skydd av skog enligt denna princip. I Norge kommer det frivilliga skyddet av skog att utvärderas 2008-2009.

Enligt en utredningsrapport som presenterades för den svenska regeringen i maj 2008 avser även Sverige att utveckla former för ökad medverkan av markägare vid bevarandeåtgärder i skogen. En del av förslagen i utredningen baserar sig på de goda erfarenheter man har i Finland beträffande nya arbetsformer, t.ex olika typer av anbudsförfaranden och samarbetsnätverk. I utredningen föreslår man att en försöksverksamhet inleds med syfte att testa några av de metoder som varit framgångsrika $\mathrm{i}$ METSO.

I Danmark ger skogslagen från 2004 Skov- og naturstyrelsen möjlighet att kartlägga särskilt värdefulla skogsmiljöer och upprätta frivilliga avtal med markägarna om skötsel och användning av sådana områden.

\section{Prioriterade teman}

På basis av diskussionerna under seminariet i Finland identifierades ett antal teman av särskild betydelse i det fortsatta utvecklingsarbetet gällande frivilligt skydd av skog.

En slutsats från seminariet var att speciellt olika aspekter av kommunikation bör uppmärksammas i det fortsatta utvecklandet och genomförandet av frivilligt skydd. En central utmaning är t.ex. att fånga upp intresset för skydd även på lång sikt, dvs att trygga ett kontinuerligt utbud av skyddsvärda områden. Möjligheterna att använda de områden som inkluderas i det frivilliga skyddet i olika projekt som fokuserar på landsbygdsutveckling och liknande aktiviteter som gynnar lokalsamhällena kunde kommuniceras aktivt till berörda aktörer.

Det är viktigt att arbetet med frivilligt skydd kontinuerligt utvärderas. Till de frågor som bör behandlas hör bl.a. utmaningar gällande kommunikationen mellan olika aktörer och kostnadseffektiviteten, dvs användningen av budgetmedel i förhållande till de naturvärden som bevaras genom frivilliga skyddsprocesser. Verksamheten bör även i övrigt karaktäriseras av långsiktighet både i fråga om budgetmedel och personresurser.

Den nordiska projektgruppen föreslår att Nordiska ministerrådet som en uppföljning av projektet ordnar en internationell konferens med temat "Frivilligt skydd av värdefull natur" 2010 eller 2011. 


\section{Inledning}

Under de senaste årtiondena har avsevärda samhälleliga resurser satsats på skydd av skog i Norden. Många av de skyddade områdena ingår idag i det europeiska nätverket Natura 2000. Inrättandet av naturreservat eller naturskyddsområden kommer även i fortsättningen att utgöra en viktig del i strävandena att bevara skogarnas biologiska mångfald. Samtidigt är det uppenbart att nya kompletterande metoder och arbetssätt behövs för att länderna skall kunna uppnå de nationella bevarandemålen. Frivilligt skydd, som bygger på ökad dialog och delaktighet i kontakterna mellan myndigheter och enskilda skogsägare, har i diskussionen framförts som ett alternativ eller komplement till traditionella skyddsmetoder.

I princip finns det många olika former av frivilligt skydd. Skogsnäringen, inklusive enskilda skogsägare och bolag, förutsätts ta sitt ansvar för bevarande av den biologiska mångfalden. Ett exempel på detta sektorsansvar är det långsiktiga målet att i Sverige undanta ytterligare arealer skog från aktivt skogsbruk på frivillig väg. I praktiken innebär sektorsansvaret att markägarna förutsätts bevara en viss andel skog på frivillig väg utan ekonomisk kompensation. Detta frivilliga åtagande är ofta knutet till certifieringssystem som PEFC och FSC.

En annan typ av frivilligt skydd bygger på att skogsägarna själva föreslår vilka områden som kunde omfattas av ett skydd antingen genom naturvårds- eller skogslagstiftningen. Ett sådant skydd kan vara antingen tidsbundet eller permanent och inkluderar som regel ekonomisk ersättning till markägaren för utebliven nyttjande- eller ägorätt.

Erfarenheter från speciellt Finland och Norge har visat att det finns en betydlig beredskap bland enskilda skogsägare att frivilligt bidra till avsättning av värdefulla skogsområden genom en sådan process. En betydande del av det formella skyddet av skog i Finland kommer framöver att genomföras enligt principen om frivillighet och som en del av biodiversitetsprogrammet för skogarna i södra Finland (METSO). I Norge har en omfattande försöksverksamhet sedan början av 2000-talet visat att frivilligt skydd har många fördelar jämfört med traditionellt skydd av skog. I Sverige föreslog en statlig utredning våren 2008 att en försöksverksamhet inleds i några områden med syfte att testa en del av de metoder för frivilligt skydd som varit framgångsrika i Finland. Även i Danmark finns en potential att utveckla och anpassa de nordiska erfarenheterna av frivilligt skydd.

Rapporten "Frivilligt skydd av skog i Norden” redogör för de initiativ som nyligen tagits i de nordiska länderna vad gäller denna nya form för skydd av skog. I rapporten ingår därtill en översikt av nationella riktlinjer och strategier som ligger till grund för befrämjandet av det frivilliga 
skyddet. Rapporten avslutas med några förslag på teman som det fortsatta arbetet kunde fokusera på, både nationellt och i ett nordiskt perspektiv. För att underlätta förståelsen av förhållandena i respektive land ingår som bilagor till rapporten nationella faktablad, som på en översiktlig nivå redogör för relevanta regelverk och organisationer inom skogs- och miljöområdet. 


\section{Frivilligt skydd av skog i Norden}

Frivilligt skydd har under de senaste åren förts fram som en viktig princip vid förverkligandet av nationella program och strategier för bevarande av den biologiska mångfalden i skog. Särskilt i Finland och Norge har en omfattande försöksverksamhet bildat grund för införandet av frivillighetsprincipen vid förverkligandet av skogsskyddet. Även i Sverige har man utvecklat skyddsformer, t.ex. naturvårdsavtal, och betonat behovet av ökad delaktighet och dialog med markägarna i det konkreta bevarandearbetet.

\subsection{Finland}

Största delen av den skyddade arealen i Finland ingår i nationella naturskyddsprogram som fastställts av regeringen. Naturskyddsprogram har upprättats för national- och naturparker, myrar och våtmarker, åsar, lundar, stränder och gamla skogar. Därtill har en särskild forsskyddslag och en lag för bevarande av ödemarkerna i norra Finland stiftats. Natura 2000 nätverket i Finland bygger till övervägande del på de områden som ingår i ovannämnda skyddsprogram och som inrättats antingen med stöd av naturvårdslagen eller ödemarkslagen. Totalt omfattar skyddsprogrammen knappt 4 miljoner hektar. Ca 98 \% av de områden som ingår i skyddsprogrammen har idag inrättas som skyddsområden eller är statsägd mark.

Naturskyddsområden inrättas i Finland antingen på statlig eller privat mark. I de fall skyddet förverkligas genom privata skyddsområden erhåller markägaren kompensation för inskränkningar i nyttjandet. Markägaren kan även välja att sälja området till staten. De regionala miljöcentralerna under ledning av miljöministeriet ansvarar för det konkreta förverkligandet av skyddet. Forststyrelsen, som förvaltar de statliga skogarna, har också en viktig roll vid köp av områden till staten för naturskyddsändamål (se faktablad - Finland).

Förverkligandet av de nationella skyddsprogrammen har finansierats på basis av ett långsiktigt finansieringsprogram. Regeringens ekonomiskpolitiska ministerutskott beslöt 2005 att förlänga perioden för förverkligandet av skyddsprogrammen till utgången av år 2009. Samtidigt beslöt man om ekonomiska ramar för det återstående arbetet. Den totala finansieringen för förverkligandet av skyddet under perioden 1995-2009 är enligt beslutet 575 miljoner euro. I början av 2008 uppgick den privatägda areal där ett skydd ännu inte förverkligats till ungefär 45000 ha. Ungefär 
8,2 \% av skogsarealen (skogs- och tvinmark) i Finland är strikt skyddad, men arealen är ojämnt fördelad i landet. I södra delen av landet är andelen betydligt mindre, ca 1,8\%.

Skogslagen i Finland förnyades 1997, och innehåller sedan dess stadganden om skydd av vissa särskilda livsmiljöer i skogen (se faktablad - Finland). Därtill omfattas ett antal skogsbiotoper av naturvårdslagens skyddsföreskrifter. Den inventering av värdefulla livsmiljöer som skogsförvaltningen genomförde i slutet av 1990-talet och början av 2000-talet producerade ett viktigt underlag för de hänsyn skogsbruket tar vad avser dessa viktiga livsmiljöer. Vid skogsbruksplaneringen, som till stor del hanteras av skogscentralerna, inarbetas lägesbunden information om de viktiga livsmiljöerna enligt skogslagen. Skogsägaren kan genom ett miljöstöd kompenseras ekonomiskt för ett skydd som går längre än lagens minimikrav eller i de fall skyddet skulle medföra ett betydande ekonomiskt bortfall.

Sedan början av 2000-talet har det fortsatta skyddet av skog i Finland till stor del varit knuten till den sk METSO-processen, som kan beskrivas som ett biodiversitetsprogram för skogarna i den södra delen av landet.

\subsubsection{Bevarande av skogarnas biologiska mångfald genom METSO programmet (2003-2007)}

Regeringen fattade 2002 ett principbeslut om en handlingsplan för att säkerställa bevarandet av den biologiska mångfalden i södra Finland, västra delen av Uleåborgs län och sydvästra delen av Lapplands län - dvs METSO-programmet. Behovet av ett nytt program motiverades bl.a. med ett bristfälligt skydd av skog i de södra delarna av landet. Ett utökat skydd skulle i praktiken mest innebära åtgärder på privatägd mark. Mot bakgrund av erfarenheter från genomförandet av Natura 2000 programmet ville man även föreslå nya arbetsmetoder, som i högre grad än tidigare betonade delaktighet och dialog med markägarna. METSOprogrammet 2003-2007 innehöll inga kvantitativa mål för det fortsatta långsiktiga skyddet av skog.

Under perioden 2003-2007 genomfördes enligt riktlinjerna i handlingsplanen aktiviteter som syftade till att bevara livsmiljöer eller naturtyper samt strukturella drag av väsentlig betydelse för biodiversiteten i skogarna. Åtgärderna fokuserade både på traditionella arbetsmetoder så som inrättande av reservat inklusive restaurering av biotoper, men också nya koncept med utgångspunkt $\mathrm{i}$ behovet av ökad dialog och frivillighet $\mathrm{i}$ kontakterna mellan skogsägare, rådgivningsorganisationer och skogsägare. METSO finansierades av miljöministeriet och jord- och skogsbruksministeriet.

Som en del av handlingsplanen och som stöd för den fortsatta utvärderingen genomfördes ett flertal omfattande forskningsprogram inriktade på 
skogarnas biodiversitet. Ett av programmen producerade t.ex. betydande ny kunskap om rödlistade arter med sin huvudsakliga förekomst i skogen.

Nya arbetssätt för att utveckla konceptet med frivillighet testades i pilotprojekt i ett flertal regioner. Pilotprojekten, som genomfördes i samarbete mellan skogs- och miljöförvaltningarna, inriktade sig på nya skyddsformer av typ naturvärdeshandel, samarbetsnätverk och naturvårdsprojekt i brukade skogar.

METSO-programmet utvärderades 2006-2007. Erfarenheterna från pilotprojekten var överlag positiva, och de metoder som testades föreslås till stor del ingå i det nya programmet för perioden 2008-2016. METSOprocessen visade i likhet med utvärderingen av det nationella biodiversitetsprogrammet 1997-2005 att det fortfarande finns ett behov av att komplettera det nuvarande nätverket av skyddsområden. Miljöministeriet tillsatte därför i april 2007 en arbetsgrupp med uppgift att utarbeta ett förslag till handlingsplan för bevarande av den biologiska mångfalden $\mathrm{i}$ skogarna i södra Finland för perioden 2008-2016. Våren 2008 fattade regeringen på basis av utredningsarbetet ett principbeslut om förverkligandet av det fortsatta skyddet av skog i södra Finland.

\subsubsection{METSO 2008-2016}

Den av miljöministeriet tillsatta arbetsgruppen för utarbetandet av en handlingsplan för den biologiska mångfalden i skogarna i södra Finland presenterade sitt förslag i januari 2008. Till arbetsgruppens främsta uppgifter hörde att föreslå nya metoder för bevarande av skogarnas biologiska mångfald inklusive arbetsformer för ett utvidgat samarbete mellan de olika aktörerna i skogen. Arbetsgruppen samlade representanter från skogs- och miljömyndigheter, skogsindustrin, miljöorganisationer, kommunerna och ett flertal skogliga branschorganisationer. Geografiskt omfattar handlingsplanen samma område som under försöksperioden 20032007, dvs södra Finland, västra delen av Uleåborgs län och sydvästra delen av Lapplands län.

Handlingsplanen innehåller 14 olika åtgärdsförslag som syftar till en gynnsam utveckling av den biologiska mångfalden i skogarna fram till år 2016. Målet kan nås genom att förbättra nätverket av skyddsområden, upprätthålla och utveckla naturvården i de brukade skogarna, förstärka kunskapsbasen och genom att fördjupa samarbetet mellan skogs- och miljösektorn inklusive skogsägare och skogsfackmän. Förutom inrättande av nya skyddsområden inkluderar handlingsplanen restaurering av befintliga skyddsområden, inventeringar av vissa naturtyper och arter, rådgivning och information samt andra åtgärder som t.ex. tryggande av mångfalden i kommunernas skogar. Frivillighet, samarbete och kostnadseffektivitet har identifierats som ledande principer i det fortsatta arbetet.

Under försöksperioden testades handel med naturvärden och upprättande av tidsbundna avtal mellan myndigheter och skogsägare. Arbets- 
gruppen föreslår att dessa metoder tas i bruk i full skala som nya instrument för skydd av skog under perioden 2008-2016. Med hjälp av särskilda naturvårdsbiologiska urvalskriterier försöker man inrikta bevarandeåtgärderna på ett från naturvårdssynpunkt optimalt sätt. Arbetsgruppen formulerade även kvantitativa mål för det fortsatta bevarandet av olika naturtyper i skogen. En första utvärdering av åtgärderna kommer att genomföras 2010.

Naturvårdsbiologiska urvalskriterier

Utgående från kunskapen om vilka livsmiljöer och strukturella drag som är särskilt viktiga för mångfalden preciserades ett antal naturvårdsbiologiska urvalskriterier. Syftet med dessa kriterier är att erbjuda stöd för beslut om vilka områden som bör skyddas genom naturvärdeshandel, men kriterierna är också användbara vid utformandet av hänsyn i de brukade skogarna. Som exempel på livsmiljöer särskilt viktiga för mångfalden kan nämnas lundar, moskogar med stort inslag av död ved, solexponerade åsar, lövsumpskogar, skog på kalkberg och ultrabasisk mark. Viktiga strukturella element är t.ex. död ved (lågor, högstubbar, torrakor, vindfällen etc.), gamla lövträd och speciellt asp, björk, sälg och rönn, grov brandskadad ved, områden påverkade av grundvatten. På basis av nuvarande kunskap om förekomsten av viktiga livsmiljöer definierade arbetsgruppen kvantitativa mål för ett fortsatt skydd av skog (tabell 1). Beräkningen baserar sig huvudsakligen på information från riksskogstaxeringen, den riksomfattande kartläggningen av viktiga livsmiljöer (se faktablad - Finland) och arealuppgifter om det befintliga skyddet. Arbetsgruppen indikerade också vilken form av skydd som kunde bli aktuell, dvs permanent och tidsbundet skydd enligt naturvårdslagen eller handel med naturvärden enligt lagen om finansiering av ett hållbart skogsbruk.

Under 2008 kommer kriterierna att ytterligare konkretiseras och vidareutvecklas. Praktiska anvisningar för tillämpningen av kriterierna kommer att utarbetas för arbetet på regional nivå. Därtill kommer regionala mål för skogs- och miljöcentralerna att formuleras vad avser förverkligandet av skyddet. Utvecklandet av samarbetsformer mellan skogs- och miljöcentralerna är ett annat tyngdpunktsområde i METSO processen under åren 2008-2009. 
Tabell 1 Kvantitativa mål för skydd av naturtyper i skog enligt handlingsplanen för den biologiska mångfalden i skogarna i södra Finland 2008-2016 ("METSO II")

\begin{tabular}{|c|c|c|c|c|}
\hline & $\begin{array}{l}\text { Permanent skydd } \\
\text { (Naturvårdslagen) }\end{array}$ & $\begin{array}{r}\text { Tidsbegränsat } \\
\text { skydd } \\
\text { (Naturvårds-lagen) }\end{array}$ & $\begin{array}{r}\text { Permanent och } \\
\text { tidsbesgränsat } \\
\text { totalt } \\
\text { (Naturvårdslagen) }\end{array}$ & $\begin{array}{r}\text { Naturvärdeshan- } \\
\text { del i ekonomi- } \\
\text { skogar } \\
\text { (Lag om finansie- } \\
\text { ring av ett hållbart } \\
\text { skogsbruk) }\end{array}$ \\
\hline & ha & ha & $\mathrm{Ha}$ & ha \\
\hline Lundar & $4000-9500$ & $800-9500$ & $4800-19000$ & $15000-32000$ \\
\hline $\begin{array}{l}\text { Moskogar med rikligt av } \\
\text { rötskadade träd }\end{array}$ & $62000-108000$ & $1000-5000$ & $63000-113000$ & $40000-68000$ \\
\hline Skogar nära små vattendrag & $1000-5000$ & $2500-4000$ & $3500-9000$ & $5000-10000$ \\
\hline $\begin{array}{l}\text { Trädbevuxna myrar och } \\
\text { kanter av skog kring dessa }\end{array}$ & $15000-30000$ & - & $15000-30000$ & $5000-10000$ \\
\hline $\begin{array}{l}\text { Lövsumpskogar och alluviala } \\
\text { skogar }\end{array}$ & $1000-5000$ & $250-1000$ & $1250-6000$ & $250-2000$ \\
\hline Solexponerade åsar & $100-150$ & $250-600$ & $350-750$ & $100-400$ \\
\hline $\begin{array}{l}\text { Mångfaldsobjekt på landhöj- } \\
\text { ningskusten }\end{array}$ & $4000-7500$ & $1000-1500$ & $5000-9000$ & $3000-6000$ \\
\hline Trädbevuxna vårdbiotoper & - & $150-2000$ & $150-2000$ & $100-1000$ \\
\hline $\begin{array}{l}\text { Skogsliknande livsmiljöer på } \\
\text { kalkberg och ultrabasisk mark }\end{array}$ & $100-500$ & $100-300$ & $200-800$ & $100-200$ \\
\hline $\begin{array}{l}\text { Skogbevuxna berg i dagen, } \\
\text { stup och blockfält som är } \\
\text { betydande för mångfalden }\end{array}$ & $1000-4000$ & $1500-4000$ & $2500-8000$ & $13000-43000$ \\
\hline SAMMANLAGT & $88200-169650$ & $7550-27900$ & $95750-197550$ & $81550-172600$ \\
\hline
\end{tabular}

Instrument för bevarande av mångfalden enligt METSO

Enligt handlingsplanen 2008-2016 kommer ett flertal olika skyddsinstrument att användas för skydd av värdefulla skogar. Den juridiska grunden för skyddet består dels av stadganden i naturvårdslagen, dels stadganden i lagen om finansiering av ett hållbart skogsbruk. Naturvårdslagen kommer primärt att användas för områden där skyddet blir permanent eller av permanent karaktär, medan lagen om finansiering av ett hållbart skogsbruk i huvudsak skall tillämpas för områden är mindre till arealen och där aktiv skötsel behövs för att trygga naturvärdena. Merparten av de beräknade kostnaderna uppkommer vid förverkligandet av skyddet enligt naturvårdslagen, dvs för inrättande av naturskyddsområden. Arealmässigt är skillnaderna mellan de två huvudtyperna av skydd inte lika markant (se tabell 1).

\section{1) Permanent skydd}

Det permanenta skyddet av skog kommer i huvudsak att inriktas på områden som är bestående till sin karaktär, t.ex. skogar med ett stort inslag av död ved. Vid urval av områden tillämpas de naturvårdsbiologiska kriterierna. Skyddet grundar sig alltid på frivillighet, dvs skogsägaren erbjuder potentiella områden för skydd, och den fortsatta processen inklusive 
förhandlingar med skogsägaren hanteras av den regionala miljöcentralen eller Forststyrelsen. Skyddet kan förverkligas antingen genom att inrätta ett privat naturskyddsområde eller genom att området säljs till staten. Det permanenta skyddet enligt naturvårdslagen skulle enligt handlingsplanen öka med ca 90 - 170000 ha under perioden 2008-2016.

\section{2) Tidsbundna avtal}

Sedan 1997 har det varit möjligt att upprätta tidsbundna med stöd av lagen om finansiering av ett hållbart skogsbruk, och de områden där avtal upprättas och miljöstöd betalats har primärt berört sådana viktiga livsmiljöer enligt skogslagen, där skyddet medfört kostnader utöver lagens miniminivå (se faktablad - Finland). METSO skulle vad gäller tidsbundna avtal i princip bygga vidare på detta system. Den viktigaste principiella skillnaden är att denna handel med naturvärden utgår från de naturvårdsbiologiska kriterierna, och naturvärdeshandeln skulle troligen beröra större områden än de som hittills erhållit miljöstöd. Många skogsägare prioriterade tidsbundna avtal som skyddsform i pilotprojekten 2003-2007.

I likhet med permanent skydd utgår tidsbundna avtal alltid från skogsägarens frivilliga intresse att upprätthålla eller öka naturvärdena i en skog som uppfyller ett eller flera av de naturvårdsbiologiska kriterierna. Den regionala skogscentralen ansvarar för upprättande av avtal med skogsägaren och ersättning betalas enligt lagen om finansiering av ett hållbart skogsbruk. Enligt METSO kan ett tidsbundet skydd även förverkligas enligt naturvårdslagen, och processen hanteras då av den regionala miljöcentralen. Handel med naturvärden och andra naturvårdande åtgärder i de brukade skogarna skulle enligt arbetsgruppens förslag omfatta 82000 173000 ha till år 2016 (tabell 1).

\section{3) Naturvårdsplaner- och projekt}

Bevarandet av den biologiska mångfalden i privata skogar kan också befrämjas genom att utveckla de fastighetsvisa skogsbruksplanerna i en riktning som motsvarar principerna för METSO. I en särskild naturvårdsplan kunde åtgärder för bevarandet av mångfalden preciseras jämsides med andra skogsvårdsinsatser. I handlingsplanen föreslås att man utarbetar en modell för hur naturvården på enskilda fastigheter kunde utvecklas med hjälp av naturvårdsplaner.

I de fall flera fastigheter önskar samarbeta om naturvårdande åtgärder kunde enskilda större naturvårdsprojekt genomföras. Sådana aktiviteter kunde t.ex. inkludera åtgärder för att skapa en kontinuerlig tillgång på död ved eller brända områden, aktiviteter som befrämjar rekreation och även viltvårdande projekt. Även restaurering av myrar och sumpskogar, vård av solexponerade livsmiljöer och bevarande av enskilda större trädgrupper kunde ingå i sådana naturvårdsprojekt. Arbetsgruppen föreslog att ett hundratal naturvårdsprojekt genomförs under perioden 2008-2016. 


\section{4) Samarbetsnätverk}

Genom att etablera sk samarbetsnätverk mellan flera skogsägare kunde den potential som skogarnas naturvärden representerar på ett mer systematiskt sätt tas tillvara vid utvecklandet av landsbygdens näringar. Samarbetsnätverken kunde befrämja den lokala företagsverksamheten och befolkningens engagemang i naturprojekt. Arbetsgruppen föreslår att 1020 samarbetsnätverk skapas för tryggande av naturens mångfald.

Kostnader och principbeslut om genomförandet

METSO arbetsgruppen uppskattade de totala kostnaderna för genomförandet av handlingsplanen till 733 - 1253 miljoner EUR. Merparten av denna kostnad skulle kanaliseras via miljöministeriet budget. I mars 2008 fattade regeringen beslut om de ekonomiska ramarna för METSO under perioden 2009-2012, dvs innevarande regeringsperiod. Med beaktande av tidigare finansieringsbeslut uppgår den totala budgeten för förverkligandet av programmet under femårsperioden 2008-2012 till 182 miljoner EUR.

Finansieringsbeslutet följdes av regeringens principbeslut, som fastslog riktlinjer för arbetet 2008-2016. De kvantitativa målen för skyddet kvantifierades ytterligare genom detta principbeslut. Nya naturskyddsområden - på privata markägares initiativ och enligt principen om frivillighet - skall enligt beslutet inrättas på 96000 ha till år 2016. Därtill skall Forststyrelsen skydda ytterligare 10000 ha av sina marker. Omfattningen av det skydd som kommer att genomföras i de brukade skogarna (tidsbundna avtal, naturvårdsplaner- och projekt) uppgår enligt principbeslutet till 82 000-173 000 ha.

\subsection{Sverige}

Naturreservat är den vanligaste formen för skydd av områden i Sverige. Denna skyddsform upptar totalt drygt 4 miljoner hektar. En betydande skyddad areal ingår också i landets 28 nationalparker, nästan 700000 hektar. Natura 2000 nätverket i Sverige omfattar ca 4100 områden på en sammanlagd yta av drygt 6 miljoner hektar. Ungefär 60 \% av de områden som ingår i Natura 2000 nätverket är idag skyddade genom naturreservat, nationalparker eller andra skyddsformer. Sedan början av 1990-talet kan värdefulla naturområden skyddas genom två nya instrument, dvs i form av biotopskyddsområden och genom upprättande av naturvårdsavtal.

Naturvårdsverket har det övergripande ansvaret för inrättande av naturreservat och nationalparker. Länsstyrelserna ansvar för det praktiska genomförandet av reservat. Värdering och förhandling sköts av oberoende konsulter som Naturvårdsverket upphandlar (se faktablad - Sverige). Under de senaste årtiondena har en stor del av resurserna för köp och intrångsersättning använts till skydd av skogsmark. 
Med utgångspunkt i läget 1998 har riksdagen beslutat att ytterligare 400000 hektar produktiv skog skall avsättas som naturreservat, biotopskydd eller skyddas genom naturvårdsavtal senast 2010. Därtill skall 500 000 ha undantas från skogsbruk på frivillig väg och utan ersättning (se avsnitt 2.2.1.).

Budgetåret 2008 anslog riksdagen 1,7 miljarder SEK (ca 180 milj. EUR) för biologisk mångfald inom Naturvårdsverkets ansvarsområde (nationalpark, naturreservat, naturvårdsavtal). Naturvårdsverket har avsatt ca 900 milj. SEK av budgeten för områdesskydd. Regeringen har dock aviserat en minskning av anslagen med 200 milj. SEK vardera budgetåren 2009 och 2010. Skogsstyrelsen erhöll budgetåret 2008 totalt 170 milj. SEK (ca 18 milj EUR) för bildande och skötsel av biotopskyddsområden samt tecknande och skötsel av naturvårdsavtal. Anslaget omfattar både ersättning till skogsägare och myndighetens administrativa arbete med formellt skydd.

Sedan 1991 har det varit möjligt att inrätta särskilda biotopskyddsområden för att bevara mindre områden i skogs- och jordbrukslandskapet. Skogsstyrelsen kan enligt miljöbalken besluta om biotopskydd för 19 olika biotoptyper i skog (se faktablad - Sverige). Hittills har beslut fattats om en areal på ca 20000 ha. Under perioden 1993-1998 och 20012003 genomfördes en nationell inventering av nyckelbiotoper på privatägd skogsmark. Inventeringen, som fortfarande pågår i mindre skala, är ett viktigt underlag vid urval av områden för skydd av värdefull natur bl.a genom biotopskydd och naturvårdsavtal. Skogsstyrelsens distrikt fattar beslut om biotopskyddsområden. Markägaren kompenseras för de begränsningar i användningen som skyddet medför.

Naturvårdsavtal är ett annat viktigt skyddsinstrument, som i praktiken varit tillgängligt sedan 1994 för Skogsstyrelsens organisation. Syftet med naturvårdsavtal är att bevara områden med höga naturvärden på basis av ett civilrättsligt avtal mellan markägaren och Skogsstyrelsen.Vanligen ingås avtalen för en tidsperiod på 50 år. I avtalet anges bl.a. syfte, lämpliga skötselåtgärder och bestämmelser om restriktioner i brukandet. Naturvårdsavtal på skogsmark tecknas av Skogstyrelsen, förutom i ett antal specialfall, där skogsmark kan ingå i de avtal länsstyrelserna upprättar. Naturvårdsavtal har tecknats för omkring 25000 ha skyddsvärd skogsmark. För Skogsstyrelsens avtal utgår en viss ersättning, baserad på virkesvärdet och naturvärdet, till markägaren. Länsstyrelsens naturvårdsavtal avses ge en ersättning som kompenserar för den begränsning av markanvändningen som avtalet innebär. Naturvårdsverket och Skogsstyrelsen avser att under 2008 utarbeta gemensamma riktlinjer för tillämpning av naturvårdsavtal.

I maj 2008 redovisade Skogsstyrelsen och Naturvårdsverket sitt regeringsuppdrag att föreslå kompletterande metoder vid skydd av värdefull natur. Redovisningen inkluderade en bedömning av lämpligheten att introducera delar av METSO metodiken i Sverige (avsnitt 2.2.2.). 


\subsubsection{Miljökvalitetsmålet Levande skogar och kvantitativa mål för skogsskyddet}

Som ett led i arbetet mot ett ekologiskt hållbart samhälle utformade riksdagen 1999 ett flertal miljökvalitetsmål, som beskriver ett önskvärt tillstånd för landets miljö- och kulturresurser (http://miljomal.nu). Miljökvalitetsmålen är nu 16 till antalet och de syftar till att främja människors hälsa, värna den biologiska mångfalden och naturmiljön, ta till vara kulturmiljön och de kulturhistoriska värdena, bevara ekosystemens långsiktiga produktionsförmåga och trygga en god hushållning med naturresurserna. Enligt det sk generationsmålet skall miljömålen uppnås senast 2020 (klimatmålet senast 2050).

För skog är miljömålet Levande skogar det viktigaste, men skogsfrågor behandlas även i målet för Myllrande våtmarker, Ett rikt växt- och djurliv samt i målet för Levande sjöar och vattendrag.

I slutet av 2005 antog riksdagen delmål, som konkretiserar och anger riktning för det fortsatta arbetet inom respektive miljömål. För Levande skogar har fyra delmål formulerats till år 2010. Delmålen omfattar långsiktigt skydd av skogsmark, förstärkt biologisk mångfald, skydd för kulturmiljövärden och åtgärdsprogram för hotade arter.

Måluppfyllelsen utvärderas kontinuerligt och en fördjupad utvärdering av miljömålsarbetet publicerades i mars 2008. Utvärderingen utgör ett underlag för den miljömålsproposition som väntas i årsskiftet 2008/09 och som sannolikt resulterar i ett riksdagsbeslut om miljökvalitetsmål med delmål för perioden fram till 2020.

Enligt delmålet för långsiktigt skydd skall ytterligare 900000 ha skyddsvärd skogsmark undantas från skogsproduktion till år 2010 (jämfört med läget 1998). Målet gäller skogsmark nedanför den fjällnära regionen. Mätbara mål för olika skyddsformer har formulerats; 320000 ha skall utgöras av naturreservat, 30000 ha av biotopskyddsområden och 50 000 ha skyddas med hjälp av naturvårdsavtal. Skogsägarna förväntas själva skydda minst 500000 ha på frivillig väg och utan ersättning.

Enligt den senaste utvärderingen kommer målet för långsiktigt skydd av skog inte att uppnås till 2010. Den beräknade måluppfyllelsen t o m 2007 för de formella skyddsformerna är 42 \% (naturreservat), 50 \% (biotopskyddsområde) och 39 \% (naturvårdsavtal). Enligt Skogsstyrelsens senaste uppföljning har målet för de frivilliga avsättningarna i princip uppnåtts. Totalt har därmed 670000 ha uppnåtts av det uppställda målet på 900000 ha.

Strategi för fortsatt skydd av skog

Skogsstyrelsens och Naturvårdsverket utarbetade 2005 en gemensam strategi för det fortsatta skyddet av skog genom naturreservat, biotopskyddsområden och naturvårdsavtal. Strategin relaterar till miljökvalitetsmålet för skog och anger detaljerade mål för genomförandearbetet på länsnivå och enligt förekomsten av skyddsvärd skog i olika zoner. Som 
underlag för strategin analyserades förekomsten av skyddsvärd skog nedanför fjällskogarna. Beroende på regionala förutsättningar och de olika skyddsformernas karaktär kommer tillämpningen av de aktuella skyddsformerna att variera i landets olika delar. Länsvisa strategier, med utgångspunkt och i linje med den nationella strategin, har utformats i varje län. Tonvikten ligger nationellt sett på inrättandet av reservat, men biotopskyddsområden och naturvårdsavtal kommer att vara vanligare i de södra delarna av landet jämfört med norr.

Enligt strategin skall en fördjupad dialog och samarbete med markägarna utgöra två ledande principer i det framtida arbetet. Betydelsen av markägarnas frivilliga avsättningar skall uppmärksammas, och samtidigt förutsätts större markägare och speciellt staten inkl. statsägda bolag ta ett särskilt ansvar för frivilligt skydd av skog på sina markinnehav.

Fastigheter med särskilt hög andel värdekärnor ska ges förtur i bevarandearbetet. Utvecklingsmarker ska ges en låg prioritet i skyddsarbetet i förhållande till befintliga värdekärnor. Strävan ska vara att inga värdekärnor avverkas och att en samverkan mellan formellt skydd och frivilliga avsättningar uppnås så att det kvantitativa målet fylls med så mycket skyddsvärd skogs som möjligt.

Landskapsperspektivet är av central betydelse vid det konkreta förverkligandet av olika bevarandeåtgärder. I praktiken innebär detta att länsstyrelserna och Skogstyrelsen bör beakta de regionala ekologiska förhållandena och identifiera värdetrakter, dvs områden med speciellt stor andel värdekärnor och därmed stor betydelse för den biologiska mångfalden

I ett internationellt perspektiv har Sverige ett särskilt ansvar för bevarandet av vissa skogstyper; ädellövskogar i den boreonemorala och nemorala zonen, hassellundar, lövskogar med inslag av ädla lövträd, större boreala skogsområden ( $>200$ ha) av gammelskogskaraktär, skogmyrmosaiker i den boreonemorala och nemorala zonen, barrskog på kalkhaltig mark, skärgårdsskogar. Landskapsperspektivet, prioriterade skogstyper och värdekärnans kvalitet är i sig de tre kriterier som bevarandearbetet utgår från.

\subsubsection{Kompletterande metoder vid skydd av värdefull natur}

Skogsstyrelsen och Naturvårdsverket fick i december 2007 i uppdrag av regeringen att "föreslå komplement till befintliga arbetsmetoder för bevarande av naturvärden där markägarinitierade förslag och frivillighet utgör utgångspunkten i arbetet med skydd av naturvärden”. Förslagen skall bidra till att öka måluppfyllelsen i miljömålsarbetet, förbättra kostnadseffektiviteten och samarbetsklimatet samt lyfta fram markägarna som part i arbetet. I uppdraget ingick att bedöma vilka delar av METSOprogrammet som kunde introduceras i Sverige. Uppdraget redovisades till Miljödepartementet i maj 2008. 
I utredningen presenterades 14 olika förslag till åtgärder, som fokuserade dels på komplement till befintliga arbetsmetoder, dels på andra åtgärder som kunde förbättra måluppfyllelsen och kostnadseffektiviteten i bevarandearbetet. Av de åtgärder som ingick i METSO-programmet 2003-2007 bedömde man särskilt anbudsförfaranden och samarbetsnätverk som intressanta också i ett svenskt perspektiv.

I redovisningen föreslår man bland annat att

...regeringen uppdrar åt Naturvårdsverket, Skogsstyrelsen och berörda länsstyrelser att på försök i något eller några mindre områden i landet och under en period av fem år bedriva ett arbetssätt som delvis liknar den finländska anbudstävlingen och handeln med naturvärden. Myndigheterna ska i den här försöksverksamheten ta fram och genomföra ett program med intensifierad och riktad information, marknadsföring, i syfte att markägare ska ta initiativ till formellt skydd.

...regeringen uppdrar åt Skogsstyrelsen och berörda länsstyrelser att initiera samarbetsnätverk för skydd av värdefull natur. Målet med samarbetsnätverken är att markägarna tillsammans med övriga aktörer inom ett geografiskt område med höga naturvärden aktivt och gemensamt ska dels utveckla naturvärdena inom området, dels arbeta med landsbygdsutveckling knuten till skyddet och skötseln av området. Myndigheterna bör inledningsvis ha en sammankallande funktion.

\subsection{Norge}

Även i Norge har skyddet av värdefull natur sedan 1980-talet förverkligats genom nationella skyddsprogram för bl.a. våtmarker, myrar, ädellövskogar och barrskogar. Idag är ca $14,3 \%$ av Norges areal skyddad. De flesta av skyddsområdena har inrättats i den alpina vegetationszonen. För några naturtypers del, framför allt i kust- och fjordregionerna, är skyddet ännu inte tillräckligt.

Genomförandet av fylkesvisa skyddsplaner kommer att förbättra situationen även nedanför fjällregionen. Arbetet med en nationell skyddsplan för marina områden påbörjades för några år sedan. Nationalparksplanen skall enligt planerna vara genomförd senast 2010.

De tre viktigaste skyddsformerna i Norge är nationalparker (58 \% av den totala skyddade arealen), landskapsskyddsområden (33 \%) och naturreservat (9\%). Enligt naturvårdslagen kan därtill mindre områden skyddas som naturminnen eller i form av art- eller biotopskydd. I Norge tillämpas det lagstadgade biotopskyddet i praktiken ofta i kombination med artskydd, och målet med art/biotopskydd kan t.ex. vara att skydda en växtart från plockning eller annan skada. 
Under de senaste åren har den årliga tilldelningen av budgetmedel för skydd av skog varit under 100 milj. NOK (ca 13 milj. EUR). Enligt de uppskattningar som gjorts inom miljöförvaltningen vore det möjligt att skydda drygt 68000 ha produktiv skog under de närmaste tre åren (42 600 ha på statens mark, 3500 ha på kyrkans egendom, och 25000 ha på frivillig väg efter anbud av skogsägarna). Ett genomförande av skyddet med denna ambitionsnivå skulle emellertid kräva en märkbar förhöjning av budgetanslagen.

Norge har miljöavdelningen på Fylkesmannen (länet) en central roll vid förverkligandet av skyddsprogrammen (se faktablad - Norge). Beredningen av skyddsärenden involverar också Direktoratet for naturforvaltning (DN) och miljödepartementet. Beslut om inrättande av nationalparker och naturreservat fattas genom kongelig resolusjon.

Landsomfattande inventeringar av nyckelbiotoper eller viktiga livsmiljöer har i Sverige och Finland förankring i skogs- och miljölagstiftningen. I Norge har detta arbete genomförts som en del av skogscertifieringen. Sedan slutet av 1990-talet finns i Norge en miljöstandard för hållbart skogsbruk, den sk Levende Skog-standarden. Krav på registrering och förvaltning av nyckelbiotoper inkluderades i standarden 1998. I början användes i princip samma metodik som i Sverige, men som ett resultat av ett större forskningsprojekt utvecklades på uppdrag av Landbruksdepartementet en ny metodik för registrering och urval av nyckelbiotoper. Denna metod, Miljöregistering i Skog (MiS), har som mål att mer systematiskt fånga upp arter som kunde vara hotade ifall nödvändig hänsyn inte tas inom skogsbruket.

Enligt planerna skall miljöregistreringar genomföras senast 2012 på all skogsmark där skogsbruk kan bli aktuellt. För tillfället har ca hälften av skogmarken inventerats och 1,4 \% av skogarealen i de registrerade områdena är avsatta som nyckelbiotoper. Sedan 2001 finns ett stödsystem för skogsägare med en särskilt stor andel nyckelbiotoper på sina marker. En skogsägare med ett innehav på 1000 hektar bör enligt systemet tåla begränsningar i skogsbruket utan kompensation upp till ett nettovärde av 200000 NOK.

Enligt den senaste uppdateringen av Levende skog standarden (2006) skall minst $5 \%$ av den produktiva skogsarealen förvaltas som "biologiskt viktiga områden”. I praktiken innebär detta att nyckelbiotoper och andra viktiga områden skall dokumenteras.

Frivilligt skydd har sedan 2003 varit en viktig del av genomförandet av skogsskyddet i Norge (se avsnitt 2.3.2.).

\subsubsection{Riktlinjer för skydd av skog}

På uppdrag av miljöverndepartementet och landbruksdepartementet genomfördes 2001-2002 en fördjupad utvärdering av skogsskyddet i Norge. I utvärderingens konklusioner konstaterades bl.a. att det finns en brist på 
stora, sammanhängande skogsområden och att många sällsynta och hotade arter inte omfattas av skyddet. Miljöhänsyn inom skogsbruket bedömdes vara en viktig åtgärd för att gynna artmångfalden. Utvärderingen innehöll även en kvantitativ bedömning av det fortsatta skyddsbehovet; inklusive befintliga skyddsområden uppskattades behovet till minst 4,6 \% av den produktiva skogsarealen, vilket motsvarar ett totalt behov på ca 336000 hektar.

Rikets miljötillstånd har behandlats i ett flertal betänkanden (meldinger) till Stortinget. Bevarandet av den biologiska mångfalden och skyddet av skog har varit en central del av diskussionerna. Med hänvisning till den genomförda evalueringen anser regeringen att skogsskyddet bör ökas, och att de brister som påtalats vad gäller t.ex. olika naturtyper bör uppmärksammas. Samtidigt anser man att det är viktigt att minska konfliktgraden i det fortsatta skyddsarbetet.

Det är också viktigt att bibehålla de naturvetenskapliga kriterierna för skydd enligt naturvårdslagen, vilket i sin tur förutsätter en god och enhetlig dokumentation av naturvärden i områden som är aktuella för skydd. Metodiken för registrering av naturvärden i skog har därför utvecklats under de senaste åren. I ett internationellt perspektiv har Norge ett särskilt ansvar för vissa naturtyper, som t.ex. oceaniska skogstyper, bäckklyftor och ädellövskogar.

Sammanfattningsvis bygger strategin för det fortsatta skyddet av skog på tre huvudpunkter; 1) skyddsarbetet bör fokusera på områden med höga naturvärden 2) frivilligt skydd skall utgöra en viktig del av arbetet 3) ytterligare inventeringar av skyddsvärd skog skall genomföras på offentligt ägda marker.

\subsubsection{Frivilligt skydd av skog}

I början av 2000-talet lanserade Norges Skogeierforbund en tanke om att skydd av skog kunde genomföras på frivillig väg och utgående från skogsägarorganisationens intresse att föreslå potentiellt skyddsvärda områden. I korthet bygger konceptet på att miljömyndigheterna först fastslår kriterier för vilka områden man önskar skydda, varefter skogsägarorganisationen i samråd med skogsägarna föreslår potentiella områden som uppfyller skyddskriterierna. Förverkligandet av skyddet bygger på att skogsägarna och miljömyndigheterna är eniga om fredningsvillkoren och ersättningsnivån och följer i övrigt rutinerna för hur fredningsprocesser behandlas i förvaltningen.

Pilotprojektet 2003-2005

Norges Skogeierforbund och Direktoratet for naturforvaltning genomförde 2003-2005 ett pilotprojekt om frivilligt skydd av skog. Projektets primära syfte var att inhämta erfarenheter om frivilligt skydd och analysera om denna arbetsmetod kunde tillämpas i det framtida skyddsarbetet. 
Utgående från ansvarsfördelningen mellan projektaktörerna formulerades två specifika delmål. Skogsägarnas organisationer fick i uppdrag att klargöra hur arbetet med enskilda skogsägare kunde organiseras. Miljömyndigheternas roll var att utveckla och testa praktiska rutiner för beredningen av fredningsärenden, som bygger på frivillighet och aktiv medverkan från Skogeierforbundet. Pilotprojektet genomfördes huvudsakligen i ett antal geografiskt begränsade områden i Telemark, Akershus och Hedmark fylken.

Skogeierforbundet formulerade ett antal delfrågor, som bl.a. fokuserade på metoder och arbetssätt för att hitta skyddsvärda områden, praktiska aspekter av kommunikation, beräkning av priset för den produkt, dvs skydd av skog, man önskade sälja, och procedurer för förhandlingar med myndigheterna.

Försöksverksamheten visade att det finns flera olika sätt att inhämta information om skyddsvärda områdens lokalisering. En del områden hade diskuterats i tidigare skyddsprocesser medan andra områden kartlagts antingen i MiS-projektet (miljöregistering i skog - se faktablad Norge) eller i kommunala kartläggningar. Områden hade också identifierats vid hyggesplanering enligt Levende Skogs standarder. Många skogsägare erbjöd den lokala skogsägarföreningen områden för skydd efter att ha hört om pilotprojektet. Projektets slutsats var att man även bör ta aktiv kontakt med skogsägare som har värdefulla områden. Av de 36 skogsägare som erbjöd att skydda sin skog tog 7 själva initiativet, medan 29 skogsägare antingen direkt eller indirekt kontaktades av projektet. Flera olika sätt att ta kontakt användes, både via brev och genom personliga kontakter. I båda fallen var skogsägarnas organisationer på lokal och regional nivå den aktiva parten. Skogsägarna fick redan vid den första kontakten information om procedurerna för en eventuell skyddsprocess, ett förslag till avgränsning av skyddsområdet, prisuppgifter och fredningsbestämmelser.

En annan erfarenhet från pilotverksamheten var att en nära dialog med skogsägaren vid avgränsning av området och formulering av skyddsbestämmelserna är av största vikt redan innan det formella skyddsbeslutet fattas. Det var också viktigt att erbjuda skogsägaren tillräckligt med tid för att fatta beslut om skyddet av sin mark.

Miljömyndigheterna (naturforvaltningen) konstaterade att processen tog längre tid än man ursprungligen avsett, och speciellt tidsperioden mellan det att en skyddsärende kungjorts till att ärendet sändes på utlåtande tog längre tid än beräknat. I det skede förhandlingar med skogsägarna kunde inledas förlöpte processen i princip enligt miljömyndigheternas system för beredning av fredningsärenden. Denna beredning inkluderar vanligen både mer noggranna naturinventeringar och beräkningar av virkesvolym, trädslagsfördelning etc. skogsbruksparametrar. Ofta inkluderade processen även terrängbesök med de olika aktörerna. 
Enligt den modell som utarbetats för processen gällande frivilligt skydd skall ett ärende vara avklarat senast två år efter det att Skogeierforbundet föreslagit skydd av ett område. I december 2005 blev 7 av de områden som ingick i pilotprojektet fredade. I två områden pågår ännu fredningsprocessen, men åtminstone det ena området kommer inom kort att fredas.

Fortsatt frivilligt skydd av skog

Sedan försöksprojektet avslutades 2005 har processen med frivilligt skydd på basis av markägarnas förslag fortsatt. Årligen har ett tiotal områden föreslagits som skyddsområden, och i en betydande del av dessa områden pågår idag en skyddsprocess. Arealen produktiv skog som årligen erbjudits för skydd har varierat från 4000 till 7500 ha (tabell 2). Arbetet med frivilligt skydd kommer att utvärderas 2008-2009. Målet med utvärderingen är dels att uppskatta i vilken omfattning bristerna i skyddet kan åtgärdas genom denna arbetsform, dels att utvärdera i hur hög grad själva processen är kostnadseffektiv och konfliktdämpande i förhållande till traditionella skyddsprocesser.

Tabell 2. Frivilligt skydd av skog i Norge 2003-2008. Uppgifterna är ungefärliga.

\begin{tabular}{lrr}
\hline År & $\begin{array}{r}\text { Antal områden där anbud givits } \\
\text { (inom parentes områden som inte } \\
\text { inkluderats i skyddsprocessen) }\end{array}$ & $\begin{array}{r}\text { Areal produktiv skog } \\
\text { (ha) }\end{array}$ \\
\hline 2003 & $11(1)$ & 2000 \\
2004 & $18(3)$ & 7500 \\
2005 & $30(4)$ & 5500 \\
2006 & $30(3)$ & 6000 \\
2007 & 36 & $8500^{*}$ \\
2008 & 19 & $4700^{*}$ \\
totalt & $>144$ & $\mathbf{2 5} \mathbf{0 0 0}$ \\
\hline * & & $\mathbf{c a}$
\end{tabular}

* bruttoareal

\subsection{Danmark}

Ungefär 15,5 \% av Danmarks landareal omfattas idag av någon form av skydd. Naturvårdslagen (naturbeskyttelsesloven) garanterar ett permanent skydd för vissa bestämda naturtyper enligt §3 och ger också möjlighet till fredning av särskilt värdefulla områden (fredninger). Till de naturtyper som är fredade genom $\S 3$ hör sjöar och vattensamlingar på minst $100 \mathrm{~m}^{2}$, myrar, olika typer av ängar och betesmarker (overderv), hedar samt de flesta vattendrag. Drygt $9 \%$ av landarealen omfattas av detta generella skydd.

De internationella skyddsområdena inkluderar Natura 2000-områden, dvs områden skyddade enligt EU:s habitat- och fågeldirektiv, och Ramsarområden (våtmarker skyddade enligt den internationella Ramsarkonven- 
tionen). Den totala arealen Natura 2000 områden på land uppgår till 359 100 ha (8.3 \% av landarealen), medan en betydligt större areal marina områden ingår i nätverket, dvs 1304700 ha. Skyddet av de områden som ingår i Natura 2000 nätverket förverkligas genom ett flertal olika lagar. Ett beslut om inrättande av Danmarks första nationalpark fattades 2007, och under de närmaste två åren kommer ytterligare fyra nationalparker att bildas.

Under 2000-talet har stats- och regionförvaltningen i Danmark genomgått ett flertal reformer. Länen (amten) ombildades i början av 2007 till fem regioner, och gällande naturförvaltningen övertog de 98 kommunerna en del av uppgifterna. Sedan 2007 hanterar By- og Landskabsstyrelsen, som administrativt lyder under miljöministeriet, överordnade frågor inom natur- och vattenförvaltning samt planläggning, bl.a. Natura 2000 frågor och andra fredningsärenden. Styrelsen stöder även kommunerna i deras arbete med natur- och planläggningsfrågor. Det konkreta arbetet hanteras av styrelsens sju regionala miljöcenter, som är inordnade i By- og Landskapsstyrelsens administration (se faktablad - Danmark).

Skov- og naturstyrelsen är också en del av miljöministeriet, och till uppgifterna hör att förvalta statens natur- och skogsarealer på ca 200000 ha. Styrelsen har även det överordnade ansvaret för etablerandet av Danmarks nationalparker. Förutom den centrala enheten i Köpenhamn har styrelsen 19 lokala enheter runtom i landet.

Nyckelbiotopsbegreppet har i Danmark främst använts i de statligt förvaltade skogarna. Värdefulla naturområden registreras som en del av den löpande skogsbruksplaneringen och enligt principerna för ett hållbart skogsbruk. I praktiken sammanfaller de värdefulla områdena i skog ofta med definitionen för § 3 områden enligt naturvårdslagen.

Till de viktigastestyrmedlen inom skogs- och naturvårdspolitiken hör naturvårdslagen och skogslagen. Därtill ingår bestämmelser om skog och natur bl.a. i planlagen (planloven), lagen om lantbruksmark (lov om drift af landbrugsjorder) och nationalparkslagen (nationalparkloven). Till de viktigaste enskilda strategierna och riktlinjerna för naturförvaltning hör målet att bromsa tillbakagången av biodiversitet fram till 2010.

\subsubsection{Frivilliga avtal enligt naturvårdslagen och skogslagen}

I Natura 2000 nätverket ingår totalt ca 60000 hektar "fredskov", dvs skog som enligt skogslagen är reserverad för skogsbruk. Denna areal inkluderar även habitat eller naturtyper som ingår i habitatdirektivet. Totalt har 16000 ha naturtyper upptagna på direktivets bilaga 1 dokumenterats. Genom att upprätta särskilda skötsel- och handlingsplaner för Natura 2000 områden strävar man efter att uppfylla habitatdirektivets stadganden om att uppnå en gynnsam bevarandestatus för naturtyperna och arterna. Vid upprättandet av handlingsplanerna är det möjligt at tmed markägarna 
ingå frivillig avtal, som omfattar bestämmelser om skötsel av specifika naturtyper inkl. skog.

Sedan 2004 ger även Skogslagens § 25 möjlighet att genomföra registreringar av särskilt värdefulla naturtyper i skog, som inte omfattas av vare sig habitatdirektivet eller andra typer av skydd. SNS har möjlighet att ingå frivilliga avtal med markägarna om skötsel av sådana områden, och för tillfället utformas ett stödsystem för detta ändamål. 



\section{Prioriterade teman}

På basis av diskussionerna under seminariet i Eura och den föreliggande översikten av arbetet med frivilligt skydd i de nordiska länderna har projektgruppen identifierat ett antal teman av särskild betydelse i det fortsatta utvecklingsarbetet.

\section{Kommunikation och processer som stöder lokal medverkan}

En väl genomförd kommunikationsprocess är av avgörande betydelse för hur framgångsrikt konceptet med frivilligt skydd kommer att bli under de närmaste åren. Det övergripande syftet bör vara att öka medvetenheten och kunskapen om de möjligheter det frivilliga skyddet kan medföra. Målgrupperna är av varierande typ; allmänheten och politiker bör informeras om frivilligt skydd, men även olika myndigheter, organisationer och framför allt skogsägarna befinner sig i en nyckelposition.

En central utmaning är t.ex. att fånga upp intresset för skydd även på lång sikt, dvs att trygga ett kontinuerligt utbud av skyddsvärda områden. Riktade informationsinsatser med beaktande av de regionala och lokala förhållandena är nödvändiga speciellt i ett inledande skede. Förutom information om vilka typer av skog man önskar skydda är det även viktigt att erbjuda exempel på hur olika skyddsinstrument kan användas i varierande situationer. Vid utarbetandet av informationsmaterial är det nödvändigt med ett nära samarbete mellan alla relevanta aktörer. Både skogsvårdsorganisationer och medborgarorganisationer, som t.ex. naturskyddsföreningar, har en viktig roll vad gäller spridning av information och åtgärder för att finna nya skyddsvärda områden.

Möjligheterna att använda de områden som inkluderas i det frivilliga skyddet i olika projekt som fokuserar på landsbygdsutveckling och liknande aktiviteter som gynnar lokalsamhällena kunde kommuniceras aktivt till berörda aktörer.

\section{Evaluering av frivilligt skydd}

Konceptet med frivilligt skydd har testats under ett flertal år särskilt i Finland och Norge. I Finland genomfördes 2006-2007 en omfattande utvärdering av METSO-programmet inklusive erfarenheterna av nya skyddsinstrument baserade på frivilligt skydd. Enligt planerna kommer 
det frivilliga skyddet av skog i Norge att utvärderas 2008-2009. I Sverige ingick en utvärdering av METSO-programmet som en del av rapporteringen av regeringsuppdraget våren 2008 om kompletterande metoder vid skydd av värdefull natur. Regelbundna evalueringar, även innefattande fältkontroller, av hur det frivilliga skyddet bidrar till att uppfylla nationella och regionala miljömål bör även framöver utgöra en central del av arbetet med frivilligt skydd.

Till de frågor som bör behandlas hör bl.a. utmaningar gällande kommunikationen mellan olika aktörer och kostnadseffektiviteten, dvs användningen av budgetmedel i förhållande till de naturvärden som bevaras genom frivilliga skyddsprocesser.

\section{Kontinuitet i bevarandearbetet}

Skyddet av skog är en långsiktig process, som i ett flertal fall förverkligas genom mångåriga program och strategier. Ett exempel på ett sådant program är METSO, dvs biodiversitetsprogrammet för skogarna i södra Finland, som i den andra fasen omfattar perioden 2008-2016. Tillräckliga personresurser är en annan aspekt av kontinuitet i bevarandearbetet. I frågor som gäller frivilligt skydd är det av särskild stor betydelse att skapa en anda av förtroende mellan de olika aktörerna. Det är en stor fördel ifall samma personer i förvaltningarna kan engagera sig i skyddsprocesserna under en längre tid.

\section{Förslag till fortsatta nordiska insatser}

Den nordiska projektgruppen för Frivilligt skydd av skog i Norden föreslår att Nordiska ministerrådet som en uppföljning av projektet ordnar en internationell konferens med temat "Frivilligt skydd av värdefull natur". Konferensen kunde förslagsvis ordnas 2010 eller 2011. 


\section{Summary}

The main aim of the project on Voluntary protection of forests in the Nordic countries was to intensify the Nordic exchange of experiences on issues related to voluntary protection of forests. Voluntary protection was in the project defined as a process, where the forest owner has a strong interest of setting aside forests for nature conservation purposes. Furthermore, voluntary protection is characterized by a strong emphasis on dialogue, participatory approaches and enhanced communication between authorities, the forestry sector as well as landowners. Most of the conservation processes studied in the Nordic project included economic compensation to the forest owners. The project was financed by The Nordic Council of Ministers and it was carried out from February to August 2008.

The final report of the project - Voluntary protection of forests in the Nordic countries - describes recent initiatives focusing on these new approaches of protecting forests. In addition, the report includes a presentation of governmental guidelines and strategies essential for the further development of voluntary protection. In June 2008, the project organized a workshop in Eura, Finland. The workshop gathered participants from environmental and forestry administrations, forest owners associations and researchers from Finland, Sweden, Norway and Denmark. On the basis of the discussions at the workshop, proposals for themes to be further elaborated on are highlighted in the report.

\section{Permanent protection of forests}

The long-term permanent protection of forests in the Nordic countries is implemented as a part of the efforts to preserve the biodiversity. In practice, the protection of various habitats has often been carried out according to national conservation programmes as well as more targeted efforts focusing mainly on forest habitats. As members of the European Union some of the countries, i.e. Finland, Sweden and Denmark, have included a substantial amount of valuable forests in the Natura 2000 network of protected areas. Forests are included in many different types of nature conservation areas. 


\section{Valuable forest biotopes or habitats}

The forestry and environmental legislation of Finland, Sweden and Denmark includes regulations that guarantee specific forest biotopes or valuable habitats a permanent protection. In Finland, several valuable habitats are defined by the Forest Act, and these habitats are in principle automatically protected. Likewise, The Swedish Nature Conservation Act enables the establishment of habitat protection areas. Both in Finland and Sweden, extensive national inventories of valuable forest habitats have been carried out by the forest authorities. Also in Denmark, the legislation includes regulations on biotope protection. In Norway, regulations on habitat protection are not included in the legislation to the same extent, but in practice both the environmental and forestry authorities are gathering extensive information about valuable forest habitats.

The valuable forest habitats are often only small patches in the commercially managed landscape. However, the habitats can be regarded as biodiversity hot spots, and hence important for the conservation of forest biodiversity. Voluntary efforts to protect biodiversity, that is, actions going beyond the minimum legal requirements, have for instance in Finland in many cases been located in the very vicinity of valuable forest habitats as defined by the Forest Act.

\section{National strategies and guidelines for protection of forests}

Guidelines and strategies for further protection of forests have been formulated both on national and regional levels. In line with the latest decision by the Swedish parliament regarding the national environmental quality objectives, an additional 900000 hectares of forest will be exempted from commercial wood production as compared to the situation in 1998. Of these hectares, 400000 are to be established as nature reserves, habitat protection areas or covered by nature conservation agreements (referred to as legal protection), whereas 500000 hectares are expected to be set aside voluntarily without economic compensation. A national strategy for implementation of the legal protection was decided on in 2005. According to the latest evaluation of the achievement of the environmental objectives, it is unclear whether the targets for the legal protection of forests in Sweden will be reached by 2010 .

In March 2008, the Finnish Government issued a resolution for a new Forest Biodversity Programme for Southern Finland for the period 20082016 - referred to as the METSO programme. The METSO programme, drafted on experiences from an extensive pilot phase in 2002-2007, aims to halt the decline in forest biotopes and species by 2016. METSO will be implemented through ecologically effective, voluntary and cost-effective means. Enhanced collaboration between forest and environmental ad- 
ministrations, advice to forest owners, training of professional foresters and related communications work are all activities of key importance in the implementation of METSO. The governmental decision included a substantial further allocation of funds to the METSO programme in the period 2009-2012 as well as defining qualitative targets for the protection. According to METSO, an additional 96000 hectares of forests will be voluntarily established as private nature reserves or acquired by the state by 2016. In addition, 10000 hectares will be set aside as conservation areas on state owned land. METSO also includes several actions enhancing biodiversity in commercially managed forests.

According to an evaluation of the further need for protection of forests in Norway, the total need is at least $4,6 \%$ of the productive forest land. If this target is to be achieved within a reasonable time period, the allocation of funds from the state budget to protection of forests has to be increased considerably.

\section{Voluntary protection of forests}

In Finland and Norway, several pilot activities have been concluded in order to find out to what extent voluntary protection of forests could be applied as a tool when implementing forest conservation schemes. Voluntary protection - as applied in the pilot activities - is based on forest owners' willingness to propose areas to be protected. Especially in Finland, the pilot activities have in this respect included developing and testing of several innovative approaches like tendering procedures and co-operation networks.

In order to ensure as cost-effective and appropriate ways as possible to realize voluntary protection, the environmental and forestry authorities have predefined ecological site selection criteria. The criteria are used to support the processing of offers and decision making related to the tendering procedures. As a rule, sites offered for protecting have to fulfill certain minimum requirements regarding the natural values. A rather similar approach is used in Sweden when implementing the legal protection, i.e. so called high-value tracts with considerable natural values are identified on a regional scale.

Offers made by forest owners to protect valuable forest land are processed by the responsible authorities more or less according to the same procedures used in any traditional conservation process. For instance, the process includes quality checks of the areas proposed for protection. The main difference is that the initiative as a rule is taken by the forest owner, and that the succeeding negotiation is carried out on a totally voluntary basis. However, the need for protection of specific sites can also be highlighted by, for instance, environmental organizations or representatives of forest owner associations. Pilot activities in Finland and Norway have 
proved that local knowledge and well established advisory services are of crucial importance as regards the possibilities to identify potential new conservation areas.

In Norway, permanent protection by establishment of nature protection areas has been the final outcome of most of the conservation processes where voluntary protection has been applied. By 2008, more than 25000 hectares of productive forest land had been offered for protection in Norway, and the experiences of voluntary protection are in general very positive.

Also in Finland, a permanent protection is preferred in many cases. A permanent protection is especially desirable in cases where the valuable natural values develop only after a long time period. For instance, the occurrence of dead and decaying wood of high quality is usually a result of a long process. However, some habitats may also be safeguarded on a more temporary basis. In the pilot phase of METSO, in 2003-2007, it was possible to agree on temporary protection for 10 or 20 years, and many forest owners preferred this type of protection. The approach is similar to the signing of nature conservation agreements used in Sweden though the contract period is usually much longer in Sweden, as a rule 50 years. In both countries, temporary agreements ideally should be used on sites where there is a need of active management.

\section{Further efforts to promote voluntary protection}

The experiences of voluntary protection have largely been positive in Finland and Norway. Voluntary protection is the leading principle when implementing the Finnish METSO programme in 2008-2016. The Norwegian experiences of voluntary protection will be evaluated in 20082009.

Following the recommendations made by a governmental committee in May 2008, also Sweden will put more emphasis on actions aiming at a strengthened participation of forest owners in the efforts to safeguard forest biodiversity. The proposals include the introduction of several new tools and methods designed to safeguard forest biodiversity, including some closely based on the schemes tested in Finland. Especially different types of tendering procedures as well as co-operation networks were regarded as interesting in this respect.

In Denmark, the Forest Act of 2004 gives the national forest- and nature agency the possibility to survey valuable forest habitats and conclude voluntary agreements with the land owners regarding the management of such areas. 


\section{Themes to be given priority}

On the basis of the workshop discussions in Eura, Finland, the project group made some recommendations on themes that could be further elaborated on as regards voluntary protection of forests. Especially different aspects of communication were highlighted. The importance of continuous evaluations and the long term time perspective were underlined as well. Finally, the project group recommended the Nordic Council of Ministers to organize an international conference on different ways of voluntary protection, tentatively in 2010 or 2011. 



\title{
Bilagor
}

\author{
Bilaga 1: Faktablad - Finland
}

Organisation

Miljöministeriet ansvarar för den strategiska planeringen och beslut inom miljöpolitiken. Jord- och skogsbruksministeriet har motsvarande ansvar inom sitt förvaltningsområde.

Finlands miljöcentral är en forsknings- och utvecklingscentral inom miljöområdet. Till miljöcentralens uppgifter hör att bedriva forskning och utvecklingsarbete som stöder en hållbar utveckling. Finlands miljöcentral skall bl.a. producera sakkunnigtjänster för miljöministeriet, jord- och skogsbruksministeriet, de regionala miljöcentralerna och andra instanser.

På regional nivå finns 13 regionala miljöcentraler, som ansvarar för miljövård, markanvändning, naturvård, vård av kulturmiljön, styrning av byggandet samt nyttjande och vård av vattentillgångarna. Dessutom skall de regionala miljöcentralerna stöda och främja kommunernas miljöförvaltning.

Skogsbrukets utvecklingscentral Tapio är en statsunderstödd utvecklings- och sakkunnigorganisation för skogsbruket. Tapio producerar utvecklings- och sakkunnigtjänster för jord- och skogsbruksministeriet, skogscentralerna och andra instanser. Jord- och skogsbruksministeriet anförtror utvecklingscentralen uppgifter som gäller styrning av skogscentralerna med undantag av myndighetsuppgifterna.

De regionala skogscentralerna utövar tillsyn över de lagar som gäller skogsbruket. Till skogscentralernas uppgifter hör att främja och handha skogsbruksplaneringen regionalt och med avseende på enskilda lägenheter samt att planera och verkställa skogsbruksarbeten som utförs med statlig finansiering. Utvecklingscentralen Tapio och skogscentralerna står under jord- och skogsbruksministeriets styrning och tillsyn.

Forststyrelsen är ett statligt affärsverk inom jord- och skogsbruksministeriets förvaltningsområde. Affärsverkets uppgift är att på ett hållbart och effektivt sätt vårda, använda och skydda naturresurser och annan egendom som den har i sin besittning. Verket förvaltar största delen av statens skogar och de statsägda naturskyddsområdena inklusive alla nationalparker. I ärenden som gäller naturskydd leds Forststyrelsen av miljöministeriet. Forsttyrelsen har en viktig roll vid genomförandet av nationella naturskyddsprogram.

Skogsvårdsföreningarna är ideella föreningar, vilkas syfte och verksamhetsformer regleras genom en särskild lag och förordning om skogs- 
vårdsföreningar. Med skogsvårdsförening avses "en sammanslutning av skogsägare, vilken har till ändamål att på skogshushållningens område höja fackkunskapen och yrkesskickligheten bland sina medlemmar och även bland övriga skogsägare inom dess verksamhetskrets, leda och utveckla vården och nyttjandet av skogarna samt ombesörja härför erforderlig fackmannahjälp ävensom annars främja skogsbruket inom dess område”. I Finland finns ca 150 skogsvårdsföreningar.

För tillfället pågår en process som syftar till att omstrukturera betydande delar av den regionala statsförvaltningen i Finland till 2010.

\section{Regelverk}

I Finland totalförnyades naturvårds- och skogslagstiftningen under 1990talet. Bevarandet av den biologiska mångfalden är ett av de viktigaste målen både i Naturvårdslagen (1096/1996) och Skogslagen (1093/1996). Stadganden om skydd av mindre, biologiskt värdefulla områden ingår i båda lagarna.

\section{a) Naturvårdslagen}

Naturvårdslagen, som trädde i kraft samtidigt som Skogslagen, dvs 1.1.1997, innehåller stadganden om skydd av vissa särskilt värdefulla naturtyper. Tre av naturtyperna är i praktiken helt knutna till skogen, dvs. naturliga dungar som till betydande del består av ädla lövträd, hassellundar och klibbalskärr.

Enligt 29 § Naturvårdslagen får områden som hör till följande naturtyper och befinner sig i naturtillstånd eller i ett därmed jämförbart tillstånd inte ändras så att detta äventyrar naturtypens karakteristiska drag:

naturliga dungar som till betydande del består av ädla lövträd, hassellundar, klibbalskärr, sandstränder i naturtillstånd, ängar vid havsstranden, trädlösa eller av naturen trädfattiga sanddyner, enbevuxen ängsmark, lövängar, samt stora enstaka träd och trädgrupper som dominerar ett öppet landskap

De skyddade naturtyperna är noggrannare definierade i 10 § Naturvårdsförordningen (160/1997). Den regionala miljöcentralen fattar beslut om gränserna för det område som hör till den skyddade naturtypen. Miljöcentralen skall samråda med skogscentralen om avgränsningen av de trädbevuxna naturtyperna. I fråga om statligt ägda områden skall miljöcentralen samarbeta med den myndighet eller inrättning i vars besittning området är. 
b) Skogslagen och Lagen om finansiering av hållbart skogsbruk

Skogarna skall enligt skogslagen skötas och användas så att de allmänna förutsättningarna för bevarande av livsmiljöer som är utmärkande för skogarnas biologiska mångfald tryggas. Avsikten är bl.a. att genom efterliknande av skogens naturliga utveckling upprätthålla en varierande trädslagssammansättning och beståndsstruktur samt, där situationen det medger, spara gamla trädbestånd eller gamla grova träd.

Livsmiljöer som är särskilt viktiga för skogarnas mångfald är

1. omedelbara närmiljöer för källor, bäckar och sådana rännilar som bildar bäddar för fortgående rinnande vatten samt omedelbara närmiljöer för små tjärnar,

2. ört- och gräskärr, ormbunkskärr samt lundkärr och sådana brunmossar som är belägna söder om Lapplands län,

3. bördiga mindre lundområden,

4. små skogsholmar med fastmarksskog på odikade torvmarker,

5. klyftor och raviner,

6. stup och skogsbestånd vid stupens nedre del, samt

7. sandfält, berg i dagen, stenbunden mark, blockfält, trädfattiga torvmarker och svämängar som i virkesproduktionshänseende avkastar mindre än lavmoar.

Enligt skogslagens motiveringar är de livsmiljöer som omfattas av lagen i allmänhet små, de avviker från den övriga skogsnaturen och de är viktiga miljöer för vissa sällsynta eller krävande arter. Om livsmiljöerna befinner sig i naturtillstånd eller ett tillstånd som påminner om detta samt avviker tydligt från omgivningen, skall de skötas och användas så att livsmiljöernas särdrag bevaras. De värdefulla livsmiljöerna är närmare definierade i Skogsförordningen (1200/1996).

Om de ekonomiska kostnaderna för att bevara miljöernas särdrag inte är ringa skall skogscentralen enligt ansökan bevilja tillstånd att handha skötseln och användningen på ett sådant sätt, att bortfallet blir ringa för den som saken gäller. Alternativt kan skogscentralen bevilja ett miljöstöd, som ersätter den del av kostnaderna som överstiger definitionen "ringa" .

I slutet av 1990-talet och början av 2000-talet genomfördes en nationell kartläggning av värdefulla livsmiljöer. Kartläggningen producerade ett viktigt underlag för de hänsyn skogsbruket tar vad avser dessa viktiga livsmiljöer. Vid skogsbruksplaneringen, som till stor del hanteras av skogscentralerna, inarbetas lägesbunden information om de viktiga livsmiljöerna enligt skogslagen

Enligt Lagen om finansiering av hållbart skogsbruk är det också möjligt att antingen helt eller delvis finansiera särskilda projekt för vård av skogsnaturen. Stöd kan t.ex. erhållas för vård och iståndsättning av viktiga livsmiljöer som sträcker sig över flera lägenheters områden eller återställande av dikningsområden med viktiga naturvärden. Projekt för vård 
av skogsnaturen planeras och genomförs av skogscentralerna eller under deras tillsyn.

\section{Bilaga 2: Faktablad - Sverige}

Hållbar utveckling är ett övergripande mål för staten inskrivet i grundlagen (regeringsformen). Sektorsansvaret innebär att varje sektor i samhället själv skall ta ansvar för sina miljöfrågor. Sedan 1998 har miljöpolitiken till stor del formulerats i form av mål. Totalt 16 miljökvalitetsmål redovisar långsiktigt önskvärda tillstånd, medan delmål, dvs etappmål, anger mätbara förbättringar, oftast i miljötillstånd, till en given tidpunkt.

\section{Organisation}

Huvuddelen av det statliga arbetet med miljörelaterade frågor sker i sektorsmyndigheterna. Miljödepartementet ansvarar för frågor som gäller klimatpolitik, vatten och hav, naturvård och biologisk mångfald, miljökvalitetsmålen, kemikalier, etc. Under Miljödepartementet finns sektorsövergripande myndigheter, i huvudsak Naturvårdsverket och Kemikalieinspektionen. Kulturmiljöfrågor handhas av Kulturdepartementet och Riksantikvarieämbetet. På regional nivå har länsstyrelserna ett omfattande ansvar som sträcker sig från miljöfrågor till sysselsättning, näringslivsfrågor, regional utveckling, planering etc.

Naturvårdsverket är central statlig myndighet med uppgift att bl.a. vägleda andra centrala, regionala och lokala myndigheter i miljö och tillsynsfrågor, föreslå ändringar i lagstiftningen och andra miljöpolitiska styrmedel, övervaka och rapportera om miljöns tillstånd samt handha skötsel av vissa skyddade områden.

Länsstyrelserna har det övergripande ansvaret för miljöfrågor på regional nivå. Länsstyrelsen övervakar och analyserar miljöns tillstånd i länen, sammanställer kunskapsunderlag och formulerar regionala mål för miljön. Till arbetsuppgifterna hör även inventeringar av hotade naturtyper och arter, vård och skötsel av naturreservat, nationalparker och andra skyddade områden, befrämjande av friluftslivet etc.

Tillsynen av skogsbruket utförs av Skogsstyrelsen, som är en rikstäckande sektorsmyndighet med totalt fem regioner indelade i drygt 40 lokala distrikt. Myndighetens fältpersonal utför lagtillsyn, information och rådgivning, inventeringar etc. Skogsstyrelsen sorterar under Näringsdepartementet.

\section{Skogsägande}

Hälften av skogsmarken ägs av ca 400000 privatpersoner. Många av skogsägarna är organiserade i LRF Skogsägarna, som är en riksorganisa- 
tion för de fyra skogsägarföreningarna Södra, Mellanskog, Norrskog och Norra Skogsägarna. Skogsägarföreningarnas medlemmar består av 89 000 företag som ägs av nästan 150000 skogsägare. Det övriga skogsägandet domineras av en handfull större skogsbolag samt det helstatliga Sveaskog, vars innehav omfattar ca 4,5 miljoner hektar mark, varav 3,4 miljoner hektar produktiv skogsmark. Övriga större skogsägare utgörs av ett antal allmänningar i Norrlands inland, några gods i södra Sverige samt kyrkans innehav.

\section{Regelverk}

Naturvårdslagen uppgick år 1999 i en särskild miljöbalk (1998:808), som samlar ett stort antal lagar till en helhet. I miljöbalken regleras även en del frågor med anknytning till skogsbruket, särskilt i kap 2 Allmänna hänsynsregler m.m, kap 7 Skydd av områden (nationalpark, naturreservat, kulturreservat, naturminne, biotopskyddsområde, djur- och växtskyddsområde, strandskyddsområde, miljöskyddsområde, vattenskyddsområde samt särskilda skyddade områden, t.ex. Natura 2000), kap. 11 Vattenverksamhet och kap. 12 Jordbruk och annan verksamhet (anmälan för samråd m.m).

Skogsbrukets verksamhet regleras särskilt i skogsvårdslagen (1979:429). Skogsvårdslagen har genomgått ett antal förändringar sedan 1979 varav den största skedde 1993. I den första paragrafen anges att Skogen är en nationell tillgång som skall skötas så att den uthålligt ger en god avkastning samtidigt som den biologiska mångfalden behålls. Den svenska skogspolitiken bygger således på två jämställda mål, ett miljömål och ett produktionsmål.

De nyckelbiotoper som identifieras av Skogsstyrelsen har inget omedelbart juridiskt skydd, men utgör ett viktigt underlag för myndigheternas och markägarnas arbete med skydd av värdefulla skogsmiljöer. Åtgärder som väsentligen kan skada naturmiljön är samrådspliktiga. Samråd enligt 12 kap. $6 \S$ miljöbalken innebär att en skogsägare har skyldighet att samråda inför arbetsföretag i skog som kan komma att väsentligt ändra naturmiljön. Ett samrådsförfarande kan vara tillämpbart bl.a. inför åtgärder i nyckelbiotoper.

För att bevara mindre biotoper i skogslandskapet med höga naturvärden är biotopskyddsområde ett viktigt skyddsinstrument. Skogsstyrelsen har enligt 7 kap. $11 \S$ miljöbalken möjlighet att besluta om biotopskyddsområden i 19 olika biotoptyper på skogsmark. Följande biotoper kan biotopskyddas enligt 6 § förordningen om områdesskydd enligt miljöbalken:

1. Brandfält

2. Lövbrännor

3. Äldre naturskogsartade skogar

4. Örtrika allundar 
5. Ravinskogar

6. Mindre vattendrag och småvatten med omgivande mark

7. Örtrika sumpskogar

8. Äldre sandskogar

9. Äldre betespräglad skog

10. Kalkmarksskogar

11. Rik- och kalkkärr

12. Alkärr

13. Hassellundar och hasselrika skogar

14. Källor med omgivande våtmarker

15. Myrholmar

16. Ras- eller bergbranter

17. Mark med mycket gamla träd

18. Strand eller svämskogar

19. Strand-eller vattenmiljöer som hyser bestånd av hotade eller missgynnade arter eller som har en väsentlig betydelse för hotade eller missgynnade arters fortlevnad

Naturvårdsavtal är ett skyddsinstrument som innebär att skogsägaren avstår från viss avverkning och får en ersättning som delvis motsvarar värdet av det han avstår. Ingående av naturvårdsavtal är frivilligt. Någon arealbegränsning för naturvårdsavtal finns inte.

\section{Bilaga 3: Faktablad - Norge}

Miljöförvaltningen i Norge är organiserad i Miljöverndepartementet och underliggande direktorat samt miljöavdelningar på fylkesnivå. Dessutom har fylkeskommunerna och kommunerna miljöuppgifter. Direktoratet for naturforvaltning (DN), Riksantikvaren och Statens forurensningstilsyn är de mest centrala direktoraten. Landbruksdepartementet är den högsta skogsbruksmyndigheten i Norge och har som uppgift att bl..a verka för en hållbar använding av naturresurserna. Norsk institutt for skog og landskap är en viktig institution under landbruks-departementet.

Direktoratet for naturforvaltning har både en rådgivande funktion och står för fackkunskap inom ekologi, biologi, friluftsliv och naturförvaltning inklusive skydd av områden. DN har en styrfunktion i förhållande till fylkena.

Fylkesmannen representerar statsmakten på regional, dvs fylkesnivå. Till uppgifterna hör att utöva myndighetsfunktioner vad avser t.ex. naturvårdslagen, viltlagen, olika fiskelagar, friluftslivlagen etc. Fylkesmannen har en rådgivande och styrande funktion i förhållande till kommunerna. Genom sin lantbruks-avdelning har Fylkesmannen ansvar för den regionala statliga jord- och skogsbruksförvaltningen i linje med gällande regelverk och politiska riktlinjer. 
Regeringens mål har under de senaste åren varit att ge den lokala nivån. dvs kommuner och fylkeskommuner, större inflytande bl.a. i frågor som berör naturvård (t.ex. kartläggning av biologisk mångfald, förvaltning av naturområden). Till kommunens uppgifter inom skogsområdet hör bl.a. att övervaka användningen av ekonomiska och juridiska styrmedel, strategisk planläggning, rådgivning och information. Kommunerna har ofta ett totalansvar vad gäller dessa uppgifter, baserat på nationella, regionala och lokala prioriteringar. De flesta kommuner har personal med utbildning inom skogsområdet, vilket också förutsätts enligt skogsbrukslagen.

\section{Skogsägande}

En stor del av landarealen i Norge ägs av staten. Arealerna förvaltas av det statliga företaget Statskog SF, som ägs av Landbruksdepartementet. Företaget förvaltar $1 / 3$ av Norges areal, $70 \%$ av arealen ligger i de tre nordligaste fylkena. Mindre än $10 \%$ av den produktiva skogsarealen i Norge ägs av staten.

De privata skogsägarna i Norge är i huvudsak organiserade i två organisationer, Norges Skogeierforbund och NORSKOG. Distriktsorganisationen inom Norges Skogeierforbund består av 8 skogsägarföreningar, jämnt fördelade över hela landet med undantag av Finnmark. Till föreningarnas huvuduppgifter hör att förhandla om virkespriser och att förmedla virke för medlemmarna. Föreningarna arbetar även med vägledning och information och sköter en del av medlemmarnas skogsmarker.

\section{Regelverk}

Fylkesmannen, Direktoratet for naturforvaltning och Miljøverndepartementet är ansvariga för beredningen av förslag till områdesskydd enligt naturvårdslagen. Fylkesmannen förslår områden som skall skyddas efter en lokal eller regional remissrunda, medan DN hanterar förslagen i förhållande till Miljøverndepartementet och den slutliga behandlingen i regeringen.

Den nya skogsbrukslagen trädde i kraft 1 januari 2006. Landbruksoch matdepartementet har med stöd av lagen utfärdat nya föreskrifter om hållbart skogsbruk inkl. preciseringar av miljöhänsynen. Beviljande av statliga understöd för skogsnäringen är knutna till villkor om miljöhänsyn.

Enligt den nya lagen kan restriktioner utfärdas för skogsbruket i områden med särskilda miljövärden knutna till biologisk mångfald, landskap, friluftsliv eller kulturminnen. 


\section{Bilaga 4: Faktablad - Danmark}

\section{Organisation}

På skog- och miljöområdet är Miljöministeriet Danmarks högsta myndighet. Inom Miljöministeriet handhas skog- och naturfrågorna dels av Skovog naturstyrelsen (SNS), dels av By-og landskapsstyrelsen (BLS). Den sistnämnda organisationen har det överordnade ansvaret för att skydda landskap och natur i Danmark. Detta inkluderar även genomförandet av habitatdirektivet och ramdirektivet för vatten. Skogdelen av habitatdirektivet utgör ett undantag, skogsfrågorna hanteras av SNS. Huvudintressenterna för BLS verksamhet utgörs av landets 98 kommuner och fem regioner. BLS består av fyra enheter i Köpenhamn och sju lokala miljöcenter.

Skov- og Naturstyrelsen (SNS) är den viktigaste, offentliga myndigheten vad gäller skogrelaterad natur och den direkta kontakten med skogsägarna. SNS har som sin huvudsakliga uppgift att trygga möjligheterna till naturupplevelser, restaurera natur och konkret förvalta Danmarks vilda djur och växter. Till uppgifterna hör att administrera nationalparkerna, skogsbruk och förvaltande av Miljøministeriets ca 200000 ha skogs- och naturarealer. SNS består av en central styrelse i Köpenhamn och 19 enheter (tidigare 'statsskovdistrikter') runtom i landet.

Skov- og Naturstyrelsen administrerar de övergripande lagarna för det danske skogsbruket. Samtidig förvaltar de 19 lokala enheterna de statsägda skogarna och naturområdena. Mera specifikt övervakar SNS naturskyddslagen, skogslagen, jakt- och viltförvaltningslagen, råstoflagen, delar av miljöskyddslagen samt lagen om genteknologi. SNS är även ansvarig för rådgivning, vägledning och information till kommuner och andra myndigheter samt privata. Dessutom övervakar SNS och dess enheter de privata skogarna och administrerar en mängd bestämmelser om stöd inom bl.a. skogsbruk och naturförvaltning. Utöver myndighetsuppgifterna förvaltar SNS medel avsatta till naturrestaurering (naturgenopretning) och -skötsel, skogsplantering samt friluftsliv.

Statsskovdistrikten förvaltar Danmarks statsskogar, vilka uppgår till ca 190000 ha. Ca 108000 ha av denna areal är skogbevuxen, dvs ca en fjärdedel av landets totala skogsareal. Skov- og naturstyrelsen har enligt skogslagen en särskild skyldighet att bruka skogarna mångsidigt. Sedan 2005 sköts de statliga skogsarealerna enligt naturnära principer fastslaget i det nationala skogsprogrammet 2002 och handlingsplanen for naturnära skogsbruk www.skovognatur.dk/Skov/Statsskovene/Naturnaer/.

De 19 lokala enheterna informerar privata skogsägare t.ex. om möjligheterna att söka olika typer av bidrag och om jakt och viltvårdsfrågor. I anslutning till statsskovdistrikten verkar naturvägledare och naturskolor, som har till uppgift att informera om skogarna och deras naturvärden.

År 1995 upprättades särskilda brugerråd i alla statsskovdistrikt. Syftet med brugerråd är att alla som använder skogarna skall ha inflytande på 
skötseln och inte enbart i frågor som gäller t.ex. friluftsliv. Till medlemmarna hör t.ex. Danmarks Naturfredningsforening och Friluftsrådet. Råden skall vara tydligt lokalt förankrade. Statsskovdistrikten ordnar även offentliga möten och skötselplanerna för skogarna upprättas genom en öppen process med remissrundor och diskussion.

\section{Skogsägare}

Skogsägarna i Danmark är organiserade dels i Dansk Skovforening, dels i Skovdyrkerforeninger och Hedeselskabet. Dansk Skovforening är skogsbrukets branschorganisation. Skovforeningen befrämjar det danska skogsbrukets intressen, både vad gäller näringen generellt och mer specifika frågor. Föreningen arbetar med näringspolitik, rådgivning, information och även med virkeshandel. Därtill ger föreningen utlåtanden i lagstiftningsfrågor. De flesta medlemmar är skogsägare. Därtill är en mängd personer, institutioner och företag som inte äger skog medlemmar. Föreningens verksamhet finansieras bl.a. genom projektverksamhet och avgifter för de tjänster föreningen erbjuder. Skogsägarna i Dansk Skovforening är knutna till någon av landets 10 skogskretsar, som regelbundet behandlar frågor kring virkeshandel och skogspolitik. Hedeselskabet, skogsodlingsföreningarna samt Skov- og Naturstyrelsen är också representerade i kretsarna.

Skovdyrkerforeningerne og Hedeselskabet erbjuder rådgivning och entreprenörsarbeten samt förmedlar trä- og andra skogsprodukter för skogsägarna. Inom naturförvaltningsområdet finns många konsulent/entreprenørvirksomheder som erbjuder naturrelaterade produkter och tjänster. "Landboforeningerne” förmedlar också allt högre grad tjänster knutna till naturretaurering på lantegendomar.

\section{Regelverk}

Ramarna för förvaltningen av Danmarks skogar inklusive bevarandet av den biologiska mångfalden anges av Skogslagen och Naturskyddslagen. I skogslagen finns stadganden om fredade skogar (fredskovspligt), dvs att vissa arealer permanent reserveras för skogsbruksändamål. Idag omfattas ca $85 \%$ av de danska skogarna av denna bestämmelse. De fredade skogarna skall bestå av träd, som antingen bildar sluten skog eller som inom en rimlig tid kommer att bilda skog av högstammiga träd. I de fredade skogarna kan även ingå icke skogbevuxna arealer och t.ex. myrar, hedar och ängar skall bevaras. De fredade skogarna skall skötas enligt skogslagens principer om ett mångsidigt skogsbruk.

Med Skovlovsrevisionen i 2004 blev Habitatdirektivets bestemmelser om beskyttelse af udvalgte arter og deres levesteder implementeret. Det udmøntede sig i at skovejeren har pligt til at anmelde planlagte driftsændringer og aktiviteter til Skov- og Naturstyrelsen forud for aktivitetens 
igangsættelse. Herudover skal evt. ansøgninger om aktiviteter som i forvejen kræver godkendelse eller dispensation (fx byggeri i skov) vurderes specielt mhp. effekten for naturtyper og arter (jf. Skovloven og Naturbeskyttelsesloven). Hvis opfyldelse af Habitatdirektivets krav medfører behov for at skovejeren ændrer sin drift er han/hun berettiget til kompensation for det økonomiske tab som den påkrævede driftsændring medfører.

I Skovloven blev der samtidig indført en $\S 25$ om særligt værdifuld skov, nemlig skovarealer som ikke er omfattet af Habitatdirektivets bestemmelser, men som alligevel skønnes vigtige at bevare. Processen er nu i gang og en række arealer er blevet identificeret som værende af interesse. En tillægsvejledning er under udarbejdelse, som netop har været til høring i Skovrådet men endnu ikke er offentliggjort (juni 2008).

Ett bidragssystem för privata skogsägare har etablerats med stöd i skogslagen. Det är t.ex. möjligt att erhålla ekonomiskt stöd för skogsplantering, inventering av nyckelbiotoper, stöd för inrättande av orörd skog eller till särskilda driftsformer som gynnar den biologiska mångfalden samt stöd till föryngring med lövskog (stödordningen 'bæredygtig skovdrift').

Även rådgivningsverksamheten omfattas av bidragssystemet, se nedan. Der är möjligt att erhålla understöd för privat skogsodling (stöd från EU via Landdistriktsprogrammet). Därtill kan man få understöd för etablering av mindre våtmarksområden och plantering av primärt inhemska buskar och träd i "det åbne land” med hänsyn till viltet. Slutligen är det möjligt att understöda "grønne projekter" ifall markägaren samarbetar med föreningar, myndigheter mm.

Naturskyddslagen (naturbeskyttelseloven) innehåller särskilda stadganden som gäller skogarna. Enligt naturskyddslagen gäller ett generellt skydd för vissa naturtyper så som vattendrag, sjöar, myrar, ängar, betesmarker och hedmarker med en viss storlek. Liknande stadganden finns i Skogslagen.

I statsskogarna inventeras alla naturtyper som är skyddade enligt naturskyddslagen. Naturvärdet bedöms för varje lokalitet och en skötselplan utarbetas. Nyckelbiotoperna sammanfaller ofta i praktiken med de enligt lag skyddade naturtyperna och i de privatägda skogarna innebär stödet för inventering av nyckelbiotoper ofta i praktiken en kartläggning av de flesta av naturtyperna i naturskyddslagen. 
Bilaga 5: Program för seminariet i Eura, 16-18 juni 2008

\author{
Måndag 16 juni \\ 17.00 Transport från flygplatsen i Åbo till Eura \\ 18.30 Ankomst till Eura \\ Kvällsbit
}

\title{
Tisdag 17 juni
}

$\begin{array}{ll}08.45 & \text { Välkomstord } \\ & \text { Teija Kirkkala, Pyhäjärviinstitutet } \\ & \text { Tapio Lindholm, Finlands miljöcentral } \\ & \text { Presentation av projektet, praktiska frågor } \\ & \text { Bo Storrank, Finlands miljöcentral } \\ & \text { Frivilligt skydd av skog i Sverige } \\ & \text { Johan Aberg, Skogsstyrelsen } \\ 09.15 & \text { Frivilligt skydd av skog i Norge } \\ 09.45 & \text { Nils Bøhn, Norges Skogeierforbund } \\ & \text { Asbjørn Tingstad, Direktoratet for naturforvaltning } \\ 10.15 & \text { Paus } \\ 10.30 & \text { Frivilligt skydd av skog i Danmark } \\ & \text { Tove Enggrob Boon, Københavns Universitet } \\ & \text { Tanja Olsen, Dansk skovforening } \\ 11.00 & \text { Frivilligt skydd av skog i Finland } \\ & \text { Marjukka Mähönen, jord- och skogsbruksministeriet } \\ 11.30 & \text { LUNCH } \\ 12.45 & \text { Exkursion i Satakunta } \\ & 4 \text { områden med betoning på METSO-processen } \\ \text { Ca } 19.00 & \text { bastu och kvällsbuffé }\end{array}$

Onsdag 18 juni

$\begin{array}{ll}09.00 & \text { Frivilligt skydd av skog - utmaningar och lösningsmodeller } \\ & \text { - gruppdiskussioner } \\ 11.00 & \text { Sammanfattning och avslutning } \\ 11.30 & \text { LUNCH } \\ 13.00 & \text { Avfärd till Åbo via flygplatsen }\end{array}$ 


\section{Bilaga 6: Deltagarförteckning}

\begin{tabular}{|c|c|c|}
\hline Tapio Lindholm & Finlands miljöcentral & tapio.lindholm@ymparisto.fi \\
\hline Bo Storrank & Finlands miljöcentral & bo.storrank@ymparisto.fi \\
\hline Kimmo Syrjänen & Finlands miljöcentral & kimmo.syrianen@ymparisto.fi \\
\hline Klaus Yrjönen & $\begin{array}{l}\text { Skogsbrukets utvecklings-central } \\
\text { Tapio }\end{array}$ & klaus.yrionen@tapio.fi \\
\hline Paula Horne & Pellervo ekonomiska forskningsinstitut & paula.horne@ptt.fi \\
\hline Jarmo Uimonen & Sydvästra Finlands skogs-central & jarmo.uimonen@metsakeskus.fi \\
\hline Marjukka Mähönen & Jord- och skogsbruksministeriet & marjukka.mahonen@mmm.fi \\
\hline Mikael Nordström & Forststyrelsen & mikael.nordstrom@metsa.fi \\
\hline Juha Manninen & Sydvästra Finlands miljöcentral & juha.manninen@ymparisto.fi \\
\hline Johan Åberg & Skogsstyrelsen & johan.aberg@skogsstyrelsen.se \\
\hline Tove Thomasson & Skogsstyrelsen Region Öst & tove.thomasson@skogsstyrelsen.se \\
\hline Thomas Pettersson & Naturvårdsverket & thomas.pettersson@naturvardsverket.se \\
\hline Tomas Mörtsell & Norra skogsägarna & tomas.mortsell@norra.se \\
\hline Asbjørn Tingstadt & Direktoratet for naturforvaltning & asbjorn.tingstadt@dirnat.no \\
\hline Nils Bøhn & Norges skogeierforbund & nils.boehn@skog.no \\
\hline Jan Erik Andersen & Fylkesmannen i Sør-Trøndelag & ¡an-erik.andersen@fmst.no \\
\hline Kenneth Svensson & Allskog BA & kenneth.svensson@allskog.no \\
\hline Even Bergseng & Universitetet for miljø og biovitenskap & even.bergseng@umb.no \\
\hline Tove Enggrob Boon & $\begin{array}{l}\text { Köpenhamns } \quad \text { universitet, } \\
\text { Skov\&Landskab }\end{array}$ & $\underline{\text { tb@life.ku.dk }}$ \\
\hline $\begin{array}{l}\text { Marie } \quad \text { Brammer } \\
\text { Nejrup }\end{array}$ & Skov- og naturstyrelsen & mabne@sns.dk \\
\hline Henrik Ballegaard & Skov- og naturstyrelsen & hba@sns.dk \\
\hline $\begin{array}{l}\text { Tanja } \quad \text { Blindbæk } \\
\text { Olsen }\end{array}$ & Dansk skovforening & to@skovforeningen.dk \\
\hline Marie-Louise Bretner & Dansk skovforening & mlb@skovforeningen.dk \\
\hline Teija Kirkkala & Pyhäjärviinstitutet & teija.kirkkala@pyhajarvi-instituutti.fi \\
\hline Tiina Seikkula & & tiina.seikkula@lamk.fi \\
\hline
\end{tabular}

